Article

\title{
Future Trends and Aging Analysis of Battery Energy Storage Systems for Electric Vehicles
}

\author{
Pedram Asef ${ }^{1, *(\mathbb{D}}$, Marzia Milan ${ }^{1}$, Andrew Lapthorn ${ }^{2} \mathbb{D}$ and Sanjeevikumar Padmanaban ${ }^{3} \mathbb{D}$ \\ 1 School of Physics, Engineering \& Computer Science, University of Hertfordshire, Hatfield AL10 9AB, UK; \\ m.milan@herts.ac.uk \\ 2 Electric Power Engineering Centre, University of Canterbury, Christchurch CT1 1QU, New Zealand; \\ andrew.lapthorn@canterbury.ac.nz \\ 3 Department of Energy Technology, Aalborg University Esbjerg, 6700 Esbjerg, Denmark; sanjeev@btech.au.dk \\ * Correspondence: p.asef@herts.ac.uk
}

check for updates

Citation: Asef, P.; Milan, M.;

Lapthorn, A.; Padmanaban, S. Future Trends and Aging Analysis of Battery Energy Storage Systems for Electric Vehicles. Sustainability 2021, 13, 13779. https://doi.org/10.3390/

su132413779

Academic Editor: Tomonobu Senjyu

Received: 21 November 2021

Accepted: 7 December 2021

Published: 14 December 2021

Publisher's Note: MDPI stays neutral with regard to jurisdictional claims in published maps and institutional affiliations.

Copyright: (c) 2021 by the authors. Licensee MDPI, Basel, Switzerland. This article is an open access article distributed under the terms and conditions of the Creative Commons Attribution (CC BY) license (https:// creativecommons.org/licenses/by/ $4.0 /)$.

\begin{abstract}
The increase of electric vehicles (EVs), environmental concerns, energy preservation, battery selection, and characteristics have demonstrated the headway of EV development. It is known that the battery units require special considerations because of their nature of temperature sensitivity, aging effects, degradation, cost, and sustainability. Hence, EV advancement is currently concerned where batteries are the energy accumulating infers for EVs. This paper discusses recent trends and developments in battery deployment for EVs. Systematic reviews on explicit energy, state-ofcharge, thermal efficiency, energy productivity, life cycle, battery size, market revenue, security, and commerciality are provided. The review includes battery-based energy storage advances and their development, characterizations, qualities of power transformation, and evaluation measures with advantages and burdens for EV applications. This study offers a guide for better battery selection based on exceptional performance proposed for traction applications (e.g., BEVs and HEVs), considering EV's advancement subjected to sustainability issues, such as resource depletion and the release in the environment of ozone and carbon-damaging substances. This study also provides a case study on an aging assessment for the different types of batteries investigated. The case study targeted lithium-ion battery cells and how aging analysis can be influenced by factors such as ambient temperature, cell temperature, and charging and discharging currents. These parameters showed considerable impacts on life cycle numbers, as a capacity fading of $18.42 \%$, between $25-65{ }^{\circ} \mathrm{C}$ was observed. Finally, future trends and demand of the lithium-ion batteries market could increase by $11 \%$ and $65 \%$, between $2020-2025$, for light-duty and heavy-duty EVs.
\end{abstract}

Keywords: aging analysis; battery; electric vehicle; energy storage systems; sensitivity analysis; prediction; time-series study; sustainability; life cycle analysis

\section{Introduction}

Electrification in transportation plays an essential role in decarbonization for reducing carbon discharge from the transportation sector by 2030 target. This process will be unreachable unless many researchers pay particular attention to $\mathrm{CO} 2$ emission reduction and different greenhouse gases (GHG), see [1]. Today, internal combustion engine (ICE) replacement with electrical machines [2] provides a significantly higher efficiency and is targeted worldwide, as the electrical machines can offer above $90 \%$ efficiency, while the ICE's median efficiency rate is 30\% [3]. Despite numerous benefits, the utilization of EVs remains limited compared to ICE-based vehicles, the primary issue being the energy stockpile. Currently, no technologies are comparable with the specific energy and range affordability of fossil fuels, and future goals are set to satisfy the requirement of above $200 \mathrm{Wh} / \mathrm{kg}$ energy density. The flywheels $[4,5]$ and ultracapacitors $[6,7]$ are a few alternatives to batteries. These come with the same power restriction, a complicated process from storing and planning hydrogen fuel cells $[8,9]$. However, the low range of specific power 
restricts EVs' usage because almost all reasonable choices come with increasing costs and short life cycle, which eventually limits the production of EVs [10].

Commercial electrochemical batteries are currently the essential energy stockpile candidates used in EVs. For example, LCO cathodes are still the most used among Liion batteries. However, they should be replaced due to environmental, safety, and cost considerations. A greener and safer type are LMO. LFP also offers the safest and most sustainable cathodes used in hybrid BMW i5 cars. NCA and NMC are the most promising cathodes for EVs due to their capacity. Table 1 demonstrates the specific capacity and discharge midpoint of different lithium-ion batteries. The discharge is set to the midpoint as calculated based on one voltage toward $\mathrm{Li} / \mathrm{Li}$ at $\mathrm{C} / 20$ for all cases, except $\mathrm{LNMO}$, which is $\mathrm{C} / 10$.

Table 1. Popular cathode battery materials for EVs.

\begin{tabular}{|c|c|c|}
\hline Li-ion Battery Type & Specific Capacity (mAh/g) & Discharge Midpoint (V/Li/Li) \\
\hline $\mathrm{LiCoO}_{2}(\mathrm{LCO})$ & 155 & 3.9 \\
\hline $\mathrm{LiFePO}_{4}$ (LFP) & 160 & 3.45 \\
\hline $\mathrm{LiMn}_{2} \mathrm{O}_{4}$ (LMO) & 120 & 4.05 \\
\hline $\mathrm{LiNi}_{1-\mathrm{x}-\mathrm{y}} \mathrm{Mn}_{\mathrm{x}} \mathrm{Co}_{\mathrm{y}} \mathrm{O}_{2}(\mathrm{NMC})$ & 180 & 3.8 \\
\hline $\mathrm{LiNi}_{0.8} \mathrm{Co}_{0 \cdot 15} \mathrm{Alx}_{0 \cdot 05} \mathrm{O}_{2}(\mathrm{NCA})$ & 200 & 3.73 \\
\hline $\mathrm{LiNi}_{0 \cdot 4} \mathrm{Mn}_{1 \cdot 6} \mathrm{O}_{2}(\mathrm{LNMO})$ & 134 & 4.65 \\
\hline
\end{tabular}

EVs are made with advanced electric-related components for ensuring their longlasting and efficacy runs. Factors such as selection and planning of power resources, energy stockpiles, and stockpile planning methods are important for the future of EV technology. Ensuring smooth services in EV demands planning power resources, selecting battery energy storage systems (BESS), maintaining the capacity of the stockpile cell, and causing regularity. This study [11] has reviewed the current scene of energy storage systems (ESS)s, advanced qualities of BESSs, analysis, problems, and the difficulties of current methods.

\section{Related Works}

Several review papers were published on BESS-related technologies and development [12-29]. In summary, researchers [12] have studied the state-of-the-art wired and wireless technologies in battery EVs. They introduced AC and DC charging methods, as well as conventional charging technologies. M. Naguib et al. [13] demonstrated a review on lithium-ion battery performance such as robust state of charge (SoC) prediction, and investigated on prediction algorithms used for SoC estimations. The latest status and gap in the lithium-ion battery supply chain is reported in [15], where the authors highlighted a consistent increase in demand and, subsequently, possible resource shortages. In another review paper [17], the researchers presented machine learning algorithms, such as support vector machines, neural networks, and radial basis functions for battery $\mathrm{SoC}$ and state of health $(\mathrm{SoH})$ prediction purposes. T.A. Lehtola and A. Zahedi [18] discussed battery cell cycle aging for the vehicle-to-grid operations. This review paper studied different batteries, considering the vehicle's range, capacity, and SoC. H. Karlsen et al. [21] reviewed the challenges, criteria, and solutions in temperature dependence in battery management systems used in EVs. The authors investigated the challenges in another work and provided recommendations about the energy management systems for lithium-ion batteries utilized in EVs [22]. E. Chemali et al. [23] reviewed electromechanical and electrostatic energy storage systems and EV management. They discussed batteries, ultracapacitors, and future battery chemistries. E. Hossain et al. [24] reviewed second-life battery technologies and challenges. They studied the increasing demand for batteries in EVs, where environmental effects and effective disposal of battery production were considered. The paper guided second-life battery technologies, which can ultimately reduce battery manufacturing and provide a better disposal process on a large scale. C. Vidal et al. [29] reviewed the recent publications about the impacts of low temperatures on lithium-ion batteries for EVs. This study considered a capacity loss, power loss, life degradation, safety hazard, unbalanced 
capacity, charging difficulty, thermal management system complexity, battery model and state estimation method complexity, and incremental cost. Finally, the study offered correlations and possible solutions for future investigations. The further grouping of ESSs is investigated in this paper [30], including the advantages and disadvantages of all types of ESS and their building, electric-based qualities, and usage.

Electrochemical batteries are time-dependent, defective components due to the nature of their chemical elements, which influence their performance and lifetime [31-43]. The main parameter for evaluating aging effects [31-36] is battery capacity. Battery capacity fading evaluation can be possible in real-world practices if battery indications can be properly monitored [37]. Therefore, battery calendar aging estimation is of extreme importance for developing persistent ESSs for EVs. The use of machine learning techniques [38-41], such as neural networks for prediction purposes has recently increased. Also, the development of management strategies for ESS has been reported in many papers [42-45]. To highlight some of the most recent developments:

A. E. Mejdoubi et al. [31] studied the lithium-ion battery health assessment, considered SoH, and estimated remaining useful life (RUL). They studied the aging of the battery by proposing the Rao-Blackwellization particle filter for EVs. In these studies [32,33], the researchers evaluated battery aging for EVs, considering different driving behaviors. The study showed that aggressive driving, recharging behavior, and temperature changes significantly impact battery life suppression. Concerning EV driving characteristics, B. Gao et al. [34] proposed an acceleration speed optimization considering battery aging. Their research could improve battery capacity loss by $9.6 \%$. For improving aging monitoring methods, S. H. Kim et al. [37] developed a new technique tested for lithium-ion batteries using harmonic-based analysis. Foraging prediction purposes, researchers recently applied machine learning techniques. K. Liu et al. [38] investigated gaussian process regression. The proposed method enhanced prediction performance with higher accuracy and better generalization ability. In $[39,40]$, the researchers successfully used the neural networks approach for battery aging predations. S. B. Vilsen et al. [41] studied a log-linear model which estimates battery aging. In this technique, they utilized dynamic aging profiles every week. To perform accurate predictions, R. Xiong et al. [42] developed a battery management system to study SoH in a lithium-ion battery. They employed online monitoring of SoH to estimate battery capacity and RUL. In another study [43], the researchers developed an active adaptive battery aging management system for EVs, controlling the battery capacity degradation. The strategy considered vehicle performance, including driving range, recharge time, and drivability. F. Chang et al. [44] studied the impact of current ripples on the aging of lithium batteries. They experimented with a long-term aging assessment on battery cells to investigate the effect of the current ripples in cascaded multilevel topologies. It is reported that the impact of most cascaded multilevel topologies is insignificant for lithium-ion batteries. The fast charging of lithium-ion batteries has also become popular in recent years. In reference [45], the authors performed a populationbased optimization algorithm for finding the optimum charging current patterns within a charging control strategy considering aging effects. The study is based on an electricthermal model considering battery temperature under different charging conditions.

At this stage, it is also important to stress the implications that the battery aging process may have on the environmental sustainability of EVs and the future availability of resources. In fact, due to aging effects, the demand for electrochemical batteries may increase due to the need for battery replacement during the vehicle's service life [46-52] or to a shorter vehicle life cycle, which Y. Ma et al. [53] envisaged being reduced to 8-10 years. This will inevitably pose a series of challenges for the environment at a different level of the supply chain. As noted by T. R. Hawkins et al. [48], the EVs' environmental performance across all impact categories are sensitive to the battery replacement schedules. This is mainly due to the intensity of the activities related to battery manufacturing and raw materials extraction, which contribute to a significant share of the environmental impacts of EVs [51-54], including the depletion of resources [55,56]. In battery replacement, the 
impact of manufacturing needs to be doubled in the calculation for all impact categories. If the vehicle has a shorter life cycle, the shorter timeframe should be considered in the analyses. T. R. Hawkins et al. [48] and P. Marques et al. [49,50] stressed the importance of accounting for battery replacement schedules when assessing the impact of lithium-ion batteries for automotive applications or EVs. Existing studies considered capacity fade models to estimate the number of batteries required during the vehicle life [57-59]. P. Marques et al. [49] published a study that integrates capacity fade in the LCA assessment. It was found that when aging effects are considered, battery replacement could increase up to $31 \%$ for EVs based on the type of chemistry and driving conditions. These results reflect state of the art and do not consider recycling pathways for recycling key materials used in lithium-ion batteries, potentially reducing up to $50 \%$ of material production intensity and decelerating the material depletion process [60]. However, the development of recycling facilities is critical to support the transition to electric mobility and decoupling society from the intensive consumption of finite resources [61,62].

Because of raising environmental concerns and technological limitations for the effective disposal of electrochemical batteries, battery selection, and usage criteria are required. This paper's contribution provides a systematic review of recent performance achievements, developments, and future trends of batteries for EVs. Due to concerns arising from an increase in the demand for batteries, i.e., material consumption and the harmful implications of manufacturing-related activities on the environment; the study also offers a comparative aging analysis to demonstrate the life cycle of different types of popular batteries. A sensitivity analysis is also provided to better understand the effects of other effective parameters on aging performance. Based on the historical data gathered for battery demands in EVs, the study also presented future directions using time series analysis techniques.

The paper's main highlights and findings are listed as:

- The paper provides an overview of the latest technologies and developments of electrochemical batteries used in EVs.

- The best performance was reported by $\mathrm{LiNi}_{1-x-y} \mathrm{MnxCoyO}_{2}$, whereas $\mathrm{LiFePO}_{4}$ is the greenest and safest battery.

- Capacity fading of $18.42 \%$, between $25-65{ }^{\circ} \mathrm{C}$, is studied as a function of the cycle number and cell temperature.

- The lithium-ion market will be increasing by $11 \%$ and $65 \%$, between $2020-2025$, for light-duty and heavy-duty EVs.

- The lithium-ion cell production mass will rise by $81 \%$ and $74 \%$ for both light- and heavy-duty EVs in the market between 2020-2025.

This paper is organized as follows: a systematic review of the recent developments and findings for electrochemical batteries is given in Section 2. In Section 3, battery aging is mathematically defined, and the modeling is presented. The simulation results are also discussed in this section. Based on extensive historical data on batteries' EV demand and their environmental impacts, the future trends are predicted and discussed in Section 4; and conclusions are in Section 5.

\section{Systematic Review of Recent Development in BESSs}

All regular chargeable batteries are considered electrochemical energy storage systems. These include flow batteries and other chargeable batteries [63]. In the electrochemical energy storage systems, energy is transformed into chemical power from electrical energy and again changed via a reversible function using power efficiency and physical changes. To evaluate the performance of all electrochemical rechargeable batteries, the role of several technical parameters, like SoC, SoH, DoD, operating cell temperature, aging, RUL, etc. [64-165], is inevitable in EVs. Because of the traction application's fast charging and discharging nature, accelerations and decelerations have considerable effects on the battery cycle number and battery life. The BESS market is still experiencing the impact of range anxiety of EVs, which is critically influenced by battery capacity fading and aging [166]. 
Secondary batteries (SB)s dictate the market of portable power storehouse devices used in EVs and different electric usage (Spinel $\mathrm{NixCo}_{2-\mathrm{x}} \mathrm{O}_{4}$ ) as a bifunctional air electrode for zinc-air batteries [137]. Such batteries stock electricity in chemical power, and they create electricity via an electrochemical reaction method. Normally, SB involves electrodes, anode, and another cathode, electrolytes, dividers, and cases. SB has remarkable qualities like high energy $[167,168]$, power density, leveled discharge, less resistance, small memory result, and a good range of performance in temperature. However, almost all batteries include toxic elements. Therefore, ecological consequences at the time of discharge must be considered [169]. The SBs provide high power density and a specific energy of electricity storehouse systems in most EV implementations because of cell technologies' high technologies and competitive costs $[170,171]$. For different EVs, the SB can be made of a zinc-halogen category $\left(\mathrm{Zn}-\mathrm{Cl}_{2}, \mathrm{Zn}-\mathrm{Br}_{2}\right)$, metal-air category (Fe-Air [65,66], Al-Air [64,65], Zn-Air [136-143]), sodium-beta ( $\mathrm{Na}-\mathrm{S}, \mathrm{Na}-\mathrm{NiCl}_{2}$ ), lithium high temperature (Li-AlFeS, Li-AlFeS 2 ), medium temperature lithium, such as lithium-polymer (Li-polymer) and lithium-ion (Li-ion), and batteries family, such as $\mathrm{Li}-\mathrm{NiCoAlO}_{2}, \mathrm{LiNixMnyCoz} \mathrm{O}_{2}$, $\mathrm{LiFePO}_{4}$, and $\mathrm{LiCoO}_{2}$ cathodes. Compared to other Li-ion batteries, Li-S offer higher specific energy, better safety, and a slightly wider operating temperature. They are currently under extensive development research. These high-energy lithium-ion batteries are the most utilized type within modern and emerging EVs today. Lead-acid (LA) with $\mathrm{Pb}-\mathrm{O}_{2}$ formula $[67,68]$ batteries are generally regarded as the worst choice, mainly because of their poor energy density compared to other presented batteries, as shown in Table 2. They were used, however, to replace ICE vehicles and applied for other areas such as the grid ESSs, renewable ESSs, and emergency power supply due to their low cost, temperature tolerance, safe operation, and ruggedness. The comparative performance of these batteries, presented in Table 2, is lower than nickel-based batteries (Ni-Fe, Ni-Zn, Ni-Cd, Ni-MH, $\mathrm{Ni}-\mathrm{H}_{2}$ ) [170-176]. The most recent battery candidates developed are Li-Ion [76-83], Lipolymer [84-91], and NiMH [122-128] batteries, due to significant energy density, life cycle, and operating temperature range, where the battery can provide its highest promising efficiency. The other listed batteries are undesirable for EVs; the worst kinds are $\mathrm{NaNiCl}_{2}$ [92-103], NaS, NiZn [129-135], and $\mathrm{ZnCl}_{2}$. Although $\mathrm{NaNiCl}_{2}$ and $\mathrm{NaS}$ have shown a notable life cycle, their operating temperature is the main reason for not deploying them. Vice versa, NiZn and $\mathrm{ZnCl}_{2}$ lack a reasonable life cycle, which eventually results in lower total range capability. As shown in Table 2, energy density, cut-off voltage (about $4.2 \mathrm{~V}$ ), and cell voltage are relatively higher than other types of electrochemical batteries for the lithium-ion cobalt (Li-Ion-Co) battery. Therefore, they are selected as one of the best cost-effective candidates for EV applications. Among newly developed batteries, lithium-titanate or titanium oxide batteries (e.g., $\mathrm{Li}_{4} \mathrm{Ti}_{5} \mathrm{O}_{12} \mathrm{LTO}$ ) can offer considerably long life cycles (up to 15,000 ) and high charging efficiencies $(85-90 \%)$. However, their disadvantages are low energy density and high cost. After discovering modern batteries such as lithium batteries and Li-polymer batteries, LA batteries continue to have a presence in the industry, particularly within devices whose temperatures are not regulated and durability is needed. One downside of lead-acid cells is their limited life cycle, which ranges from 400 to 2000 cycles [176,177]. Smaller versions of the LA batteries have become increasingly popular for automotive electric equipment and rescue services. While larger ones are typically used for stationary and starting, lighting, and ignition (SLI), applications have only lately been produced [178]. For example, SLI and uninterruptible power supply (UPS) batteries are usually LA batteries that have small voltages and ratings of 12,8 , and $6 \mathrm{~V}$. A valve-regulated lead-acid (VRLA) has also been used to power the EVs due to no maintenance being needed, the capability of rapid charging, low cost, and high power. Recent studies have also investigated the weight and size minimization of advanced batteries and maintaining energy density [179-181], such as VRLA batteries including gel and absorbent glass mat (AGM) batteries [182-184], which are made of fiberglass electrolytes; a solid material which contains and absorbs acid without any leakage. They require less space and have a compact volume, and their vibration resistance is higher than many other 
standard batteries $[185,186]$. This battery has a specific function that can recombine oxygen and hydrogen into the water during charging inside a unit and limit water loss. On the other hand, a gel battery is composed of the electrolyte of gel-state which is gelatinous and not solid enough to contain acid without any leakage. These batteries require controlled and slower charging as compared to many others. These batteries' corresponding challenges, strategies, and perspectives are discussed in [187-190]. For example, the risk of using gel batteries can be the bubbles of gas produced in the electrolyte. They may damage a battery permanently.

Table 2. Performance of electromechanical batteries for EVs.

\begin{tabular}{|c|c|c|c|c|c|}
\hline Batt. Type & $\begin{array}{c}\text { The Energy } \\
\text { Density }(\mathrm{Wh} / \mathrm{kg})\end{array}$ & Life Cycle & $\begin{array}{c}\text { Internal } \\
\text { Resistance }(\mathrm{m} \Omega)\end{array}$ & Cell Voltage (V) & $\begin{array}{c}\text { Charging } \\
\text { Temperature }\left({ }^{\circ} \mathrm{C}\right)\end{array}$ \\
\hline $\mathrm{Pb}-\mathrm{O}_{2}$ & 40 & 250 & $<100$ (12 V pack) & 2 & -20 to 50 \\
\hline $\mathrm{Ni}-\mathrm{Cd}$ & 62 & 1000 & 150 (6 V pack) & 1.2 & 0 to 45 \\
\hline $\mathrm{Li}$-Ion- $\mathrm{PO}_{4}{ }^{3-}$ & 115 & 1500 & $25-50^{2}$ & 3.3 & 0 to $45^{10}$ \\
\hline Li-Ion-Mn & 117 & 750 & $25-75^{2}$ & 3.8 & 0 to $45^{10}$ \\
\hline Li-Ion-Co & 170 & 750 & 17 & 3.6 & 0 to $45^{10}$ \\
\hline $\mathrm{Li}_{4} \mathrm{Ti}_{5} \mathrm{O}_{12} \mathrm{LTO}$ & 90 & 7000 & 2 (per cell) & 2.4 & 0 to 45 \\
\hline LSD-NiMH & 95 & 900 & 250 (6 V pack) & 1.2 & 0 to 45 \\
\hline Ni-MH & 90 & 400 & 250 (6 V pack) & 1.2 & 0 to 45 \\
\hline
\end{tabular}

Notes: The life cycle is reported in $80 \%$ discharge. Bold text indicates the best performance for EVs among the considered batteries. At the same time, underlined text indicates the worst performance.

Table 3 demonstrates several popular electrochemical batteries for EVs, where the anode is graphite for all presented batteries. $\mathrm{LiMn}_{2} \mathrm{O}_{4}$ has the highest nominal tension capability; $\mathrm{NaNiCl}_{2}$ has shown the greatest thermal runaway feature, while the specific energy is reported as the weakest. Also, $\mathrm{ZnOH}_{42-}$ offers the highest specific energy among others. In commercialized batteries, $\mathrm{LiCoO}_{2}$ is still the most used cathode material. It was an unbeatable cathode for decades due to its large energy density, long life, and ease of preparation. Nonetheless, the phase transition from hexagonal to monoclinic at high voltages, and the cost of cobalt and its toxicity, motivated the scientists to search for a better solution [191,192]. $\mathrm{H}_{2} \mathrm{SO}_{4}$ and hydrochloric acid $(\mathrm{HCl})$ were used as the main agent to compare the effects on cobalt and lithium extraction.

Table 3. Popular battery characteristics and requirements for EVs.

\begin{tabular}{|c|c|c|c|c|c|}
\hline $\begin{array}{l}\text { Chemistry } \\
\text { Description }\end{array}$ & $\begin{array}{c}\text { Lithium Cobalt } \\
\text { Oxide }\end{array}$ & $\begin{array}{c}\text { Lithium Manganese } \\
\text { Oxide }\end{array}$ & $\begin{array}{l}\text { Sodium-Nickel } \\
\text { Chloride }\end{array}$ & $\begin{array}{l}\text { Nickel-Metal } \\
\text { Hydride }\end{array}$ & Zinc-Air \\
\hline $\begin{array}{l}\text { Reaction formula } \\
\text { Nominal tension }(\mathrm{V})\end{array}$ & $\begin{array}{c}\mathrm{LiCoO}_{2} \\
3.60\end{array}$ & $\begin{array}{l}\mathrm{LiMn}_{2} \mathrm{O}_{4} \\
3.70\end{array}$ & $\begin{array}{c}\mathrm{NaNiCl}_{2} \\
2.85\end{array}$ & $\begin{array}{l}\mathrm{NiMH} \\
\underline{1.20}\end{array}$ & $\begin{array}{l}\mathrm{ZnOH}_{42-} \\
1.4\end{array}$ \\
\hline $\begin{array}{l}\text { Specific energy } \\
\quad(\mathrm{Wh} / \mathrm{kg})\end{array}$ & $150-200$ & $100-150$ & 94-130 & $300-400$ & $350-500$ \\
\hline Charge (C-rate) & $0.7-1$ & $0.7-1$ & 0.3 & 0.1 & 0.8 \\
\hline Discharge (C-rate) & 1 & 1 & 1 & 1 & 0.1 \\
\hline Thermal runway $\left({ }^{\circ} \mathrm{C}\right)$ & 150 & 250 & $270-350$ & $\underline{40-70}$ & $280-320$ \\
\hline
\end{tabular}

Notes: The life cycle is reported in $80 \%$ discharge. Bold text indicates the best performance for EVs among the considered batteries. At the same time, underlined text indicates the worst performance.

In the recovery of cobalt and lithium from Li-Ion battery active mass, $\mathrm{HCl}$ performs better than $\mathrm{H}_{2} \mathrm{SO}_{4}$. The actual state for cobalt and lithium recovery is $2 \mathrm{M} \mathrm{HCl}, 90 \mathrm{~min}$ of leaching time, and $60-80^{\circ} \mathrm{C}$ of leaching temperature. In this condition, the extraction ratio for $\mathrm{Co}$ and $\mathrm{Li}$ is nearly $100 \%$. The methods used for synthesizing $\mathrm{LiCoO}_{2}$ as a cathode and recycling the cobalt and lithium from spent Li-Ion batteries are mechanical, thermal, hydrometallurgical, and the sol-gel phases. The active cathode material has a good chargedischarge capability and cycling performance because of $\mathrm{LiCoO}_{2}$ powder [193-195]. Less life span, low thermal stability, and reduced specific power capability are the disadvantages 
of LiCo-based batteries. Some batteries, such as Li-Ion and Cobalt- blended Li- Ion, reduce the life span due to mainly anode thickening, solid electrolyte interface, and lithium plating during rapid charging and reduced charging [196].

A lithium-ion manganese oxide battery is a lithium-ion cell with a cathode made of manganese dioxide $\left(\mathrm{MnO}_{2}\right)$. Their issues and challenges are discussed in $[197,198]$. They vary widely for EVs, such as $\mathrm{LiNi}_{0.5} \mathrm{CO}_{0.2} 2 \mathrm{Mn}_{0 \cdot 3} \mathrm{O}_{2}$ (NCM523). Solvent-based slurry casting techniques are widely used to create these cathodes, which are harmful to the environment, energy-intensive, and time-consuming.

Longer transit distances at a lower cost have been a focus, ensuring optimum performance and reducing utilizing second-life batteries for EVs. In an approach to reduce battery production, their performance, application, feasibility, environmental impacts, economic benefits, and challenges are reported in [199-202]. They work under the same intercalation/de-intercalation principle as commercialized secondary rechargeable batteries such as $\mathrm{LiCoO}_{2}$. Earth-abundant, cheap, non-toxic, and thermally stable, cathodes dependent on manganese-oxide compounds are used. Another advanced type of battery is the lithium manganese oxide, $\mathrm{LiMnO}_{2}$; the battery uses manganese for the cathode and lithium as the anode. For the boost ion transfer, the battery is shaped like a spinel. It contains lithium chloride, which acts as an organic solvent to help electrons flow between the anode and the cathode. The lithium manganese oxide battery has several benefits that make it appealing to users. It has a large life cycle of about ten years, which ensures long-term dependability. For example, Nissan Leaf EV, in 2013, adopted $\mathrm{LiMnO}_{2}$, which offers up to 225 miles in driving range. Additionally, the reports and innovative studies on how to deal with their temperature rise and thermal management solutions can be found in [203-245].

While there is widespread consensus that the demand for EVs is growing, a substantial portion of the population remains skeptical. The key concerns are range limits, battery durability, and safety. As the market grows, Table 4 presents considerations to overcome these challenges. The recent and new manufactured EVs in the market are reported in Table 4. Their key parameters are reported, such as driving range, battery capacity, charging duration, power, and energy consumption. It is also reported that the battery size in terms of power significantly increased up to $67 \mathrm{kWh}$ in 2020, which is predicted to rise to $80 \mathrm{kWh}$ in 2030 (see [246,247] for more details). From the table, the best overall performance can be selected for Jaguar I-Pace EV400 using a lithium-ion battery, where the highest top speed, driving range, and battery capacity are provided.

Table 4. Recent and new market trends for passenger and van EVs.

\begin{tabular}{|c|c|c|c|c|c|c|}
\hline Brand & Model & Year & $\begin{array}{l}\text { Top Speed } \\
\text { (mph)/Range } \\
\text { (mi) }\end{array}$ & $\begin{array}{c}\text { Battery Capacity } \\
\text { (kWh)/Fast Charging } \\
\text { Time (h) }\end{array}$ & $\begin{array}{l}\text { Normal and Maximum } \\
\text { Battery Charging } \\
\text { Power }(\mathrm{kW})\end{array}$ & $\begin{array}{c}\text { Energy } \\
\text { Consumption } \\
(\mathrm{Wh} / \mathrm{mi})\end{array}$ \\
\hline Audi & e-tron 55 quattro & 2019 & $124 / 225$ & $86.5 / 0.46$ & $11 \mathrm{AC} / 155 \mathrm{DC}$ & 315 \\
\hline BMW & i3 & 2019 & $93 / 219$ & $42.2 / 0.5$ & $11 \mathrm{AC} / 49 \mathrm{DC}$ & 195 \\
\hline Audi & e-tron 50 quattro & 2020 & $118 / 175$ & $64.7 / 0.45$ & $11 \mathrm{AC} / 120 \mathrm{DC}$ & $\underline{365}$ \\
\hline Vauxhall * & Vivaro-e Life Elite L & 2020 & $\underline{81} / \underline{110}$ & $50 / 0.52$ & 7.4 AC/99 DC & $\overline{310}$ \\
\hline Fiat & 500e Cabrio & 2020 & $\overline{93} / \overline{135}$ & $\underline{42} / 0.45$ & $11 \mathrm{AC} / 85 \mathrm{DC}$ & 185 \\
\hline Jaguar & I-Pace EV400 & 2020 & $124 / 225$ & $90 / 0.32$ & $11 \mathrm{AC} / 262 \mathrm{DC}$ & 290 \\
\hline Tesla & 3 long range & 2021 & $91 / 145$ & $77 / 0.54$ & $11 \mathrm{AC} / 190 \mathrm{DC}$ & 190 \\
\hline Citroën & $\mathrm{e}-\mathrm{C} 4$ & 2021 & $\underline{81 / 115}$ & $45 / 0.52$ & 7.4 AC/99 DC & 205 \\
\hline Mercedes & EQA 250 & 2021 & $\overline{99} / 220$ & $66.5 / 0.55$ & $11 \mathrm{AC} / 100 \mathrm{DC}$ & 250 \\
\hline Ford & $\begin{array}{c}\text { Mustang Mach-E } \\
\text { ER }\end{array}$ & 2021 & $120 / 335$ & $88 / 0.72$ & $11 \mathrm{AC} / 150 \mathrm{DC}$ & 260 \\
\hline Tesla & Y long range & 2021 & $112 / 260$ & $72.5 / 0.31$ & $11 \mathrm{AC} / 250 \mathrm{DC}$ & 240 \\
\hline Lexus & UX $300 \mathrm{e}^{\circ}$ & 2021 & $99 / 160$ & $54.3 / 1.15$ & $6.6 \mathrm{AC} / 35 \mathrm{DC}$ & 260 \\
\hline Peugeot* & e-Traveller Long & 2021 & $\underline{81 / 115}$ & $50 / 0.52$ & $\overline{7.4 \mathrm{AC} / 99 \mathrm{DC}}$ & 325 \\
\hline BMW & $\mathrm{i} X 3$ & 2021 & $112 / 225$ & $74 / 0.52$ & $11 \mathrm{AC} / 155 \mathrm{DC}$ & 255 \\
\hline
\end{tabular}

Notes: Bold text indicates the best performance for passenger EVs among the studied cases. Whereas underlined text indicates the worst performance, and * presents van EVs. The energy consumption is calculated under standard WLTP drive cycle for this table. 
Critical safety problems in BESSs comprise temperature rises and management. Improving efficiency, range, charging, durability, and protection can be achieved by effectively handling the heat in the utilized BESS. In Table 5, several thermal cooling methods consider their efficiency and operating temperature such as air, liquid, direct refrigerant, phase change material, thermoelectric, and heat pipe. The highest efficiency could be seen for direct refrigerant and thermoelectric cooling methods. Battery thermal management advances can be found in the following review and technical papers [247-254].

Table 5. Battery thermal cooling methods for EVs.

\begin{tabular}{cccc}
\hline $\begin{array}{c}\text { Thermal Cooling } \\
\text { Methods }\end{array}$ & Efficiency $(\%)$ & $\begin{array}{c}\text { Operating } \\
\text { Temperature }\left({ }^{\circ} \mathbf{C}\right)\end{array}$ & Citations \\
\hline Air & $40-60$ & $50-200$ & {$[203-207]$} \\
Liquid & $45-75$ & $50-300$ & {$[208-214]$} \\
Direct refrigerant & $55-80$ & $25-600$ & {$[215-220]$} \\
Phase change & $50-65$ & $-20-45$ & {$[221-229]$} \\
Thermoelectric & $65-80$ & $0-150$ & {$[230-235]$} \\
Heat pipe & $50-75$ & $25-300$ & {$[236-246]$} \\
\hline
\end{tabular}

\section{Aging Analysis Considering Cell Temperature for HEVs: A Case Study}

3.1. Mathematical Equations

The HEV's powertrain is modeled to deliver power demands from the BESS to the wheels. Depending on the driving conditions, the power demand $P_{\text {demand }}$ varies, which combines both ICE and electric machine (EM) with motoring and generating capabilities. Hence, the $P_{\text {demand }}$ can be introduced into two categories, (1) braking and coasting; and (2) accelerating and cursing modes:

$$
\left\{\begin{array}{c}
(1): P_{\text {demand }} \leq 0, P_{r p b}(t)=P_{\text {demand }}(t)-\frac{P_{E M}(t)}{\eta_{t}(G R(t))} \\
(2): P_{\text {demand }}>0, P_{I C E}(t)=\frac{P_{\text {demand }}(t)}{\eta_{t}(G R(t))}-P_{E M}(t)
\end{array}\right.
$$

where $P_{r p b}$ is the regenerative power braking produced from the negative acceleration, under braking condition $P_{E M}$ is the net output power from the $E M$, and $P_{I C E}$ is the net output power from the ICE. $\eta_{t}$ is the total transmission efficiency, which is a function of gear ratio $G R$.

Battery aging analysis considering the electro-thermal effects demonstrates how the performance of the BESS can be degraded. The electro-thermal modeling of the BESS using a Thevenin circuit is considered for this study, based on [254-257]. Considering the Thevenin circuit, presented in Figure 1, the terminal voltage $U_{c}$ can be given as:

$$
U_{c}=V_{o c}(S o C, T)-U_{R s}\left(I_{L}, t\right)-\sum_{i=1}^{N} U_{R C, i}(t)
$$

where $V_{o c}$ is the open-circuit voltage, $T$ is the operating cell temperature of the battery, $I_{L}$ is the load (or battery) current, $V_{R s}$ is the instantaneous voltage drop over the ohmic internal resistance $\left(R_{0}\right)$, which is computed using $R_{0} \times \Delta I$, where $\Delta I$ indicates the step change of battery charging or discharging current. $V_{R C}$ is the transient voltage drop over the $i$ th $R C$ shown in Figure 1. 


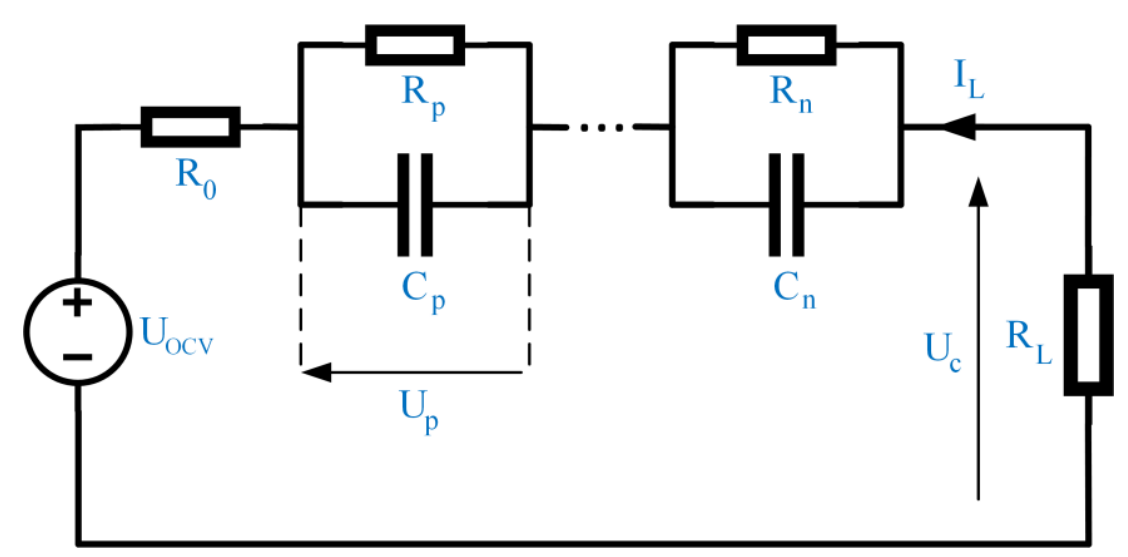

Figure 1. Battery cell model using Thevenin circuit.

In this study, the aging analysis of multiple connected lithium-ion battery cells is modeled. The effects of battery temperature on the capacity degradation and life cycle are investigated, where the battery temperature is:

$$
T_{c}(n)=T_{c}(n-1)+\frac{I_{L}^{2} R_{o}+I_{L} U_{p}+I_{L} T_{c} \frac{d U_{o c v}}{d T_{\mathcal{c}}}-h S\left(T_{c}-T_{a}\right)}{C m}
$$

where $T_{\mathcal{C}}$ is the average battery temperature, resulting from all considered battery cells $T_{c}=T_{c 1}+T_{c 2}+T_{c 3}+\cdots+T_{c n} ; h$ is the heat transfer coefficient, and $S$ is the total superficial area of battery; $U_{o c v}$ is the open circuit voltage; $T_{a}$ is the ambient temperature of the battery cells. These are varied for better understanding its impact on the battery's aging, using a global sensitivity method based on Sobol random sampling and Monte Carlo analysis. $C$ is the heat capacity of the battery cells, and $m$ is the battery total mass.

The discharging/charging functions $f_{1}$ and $f_{2}$ of the lithium-ion battery cell is:

$$
\left\{\begin{array}{c}
f_{1}\left(\dot{Q}, i^{*}, i, T_{c}, T_{a}\right)=E_{0}\left(T_{c}\right)-K\left(T_{c}\right) \frac{Q\left(T_{a}\right)}{Q\left(T_{a}\right)-\dot{Q}}\left(i^{*}+\dot{Q}\right) \\
+A e^{(-B \dot{Q})}-C \cdot \dot{Q} \\
f_{2}\left(\dot{Q}, i^{*}, i, T_{c}, T_{a}\right)=E_{0}\left(T_{c}\right)-K\left(T_{\mathcal{c}}\right) \frac{Q\left(T_{a}\right)}{\dot{Q}+0.1 Q\left(T_{a}\right)} i^{*}-K\left(T_{\mathcal{c}}\right) \\
\frac{Q\left(T_{a}\right)}{Q\left(T_{a}\right)-\dot{Q}} \dot{Q}+A e^{(-B \dot{Q})}-C \cdot \dot{Q}
\end{array}\right.
$$

where $E_{0}$ is the constant voltage; $\dot{Q}$ is the extracted capacity; $Q$ is the maximum battery capacity; $K$ is polarization resistance; $i^{*}$ is the low-frequency current dynamics; $i$ is the battery current; $A$ and $B$ are exponential voltage and capacity constant, and $C$ is the nominal discharge curve slope. To calculate the polarization resistance or constant:

$$
K\left(T_{c}\right)=K_{T_{r e f}} \cdot e^{\left(\alpha\left(\frac{1}{T_{c}}-\frac{1}{T_{r e f}}\right)\right)}
$$

where $T_{\text {ref }}$ is the reference cell temperature, and $K_{T \_r e f}$ is the constant related to $T_{\text {ref }}$. Considering the aging effects of a lithium-ion battery cell, the capacity degradation can be defined as:

$$
Q(n)=\left\{\begin{array}{c}
Q_{B O L}-\varepsilon(n) \cdot\left(Q_{B O L}-Q_{E O L}\right) \text { if } k / 2 \neq 0 \\
Q(n-1) \text { otherwise }
\end{array}\right.
$$

where $Q_{B O L}$ is the capacity of battery under the beginning of the life $(B o L)$ condition, $Q_{E O L}$ is the capacity of the battery under the end of life $(E o L)$ condition. Both are measured at the nominal (or reference) ambient temperature. $\varepsilon$ is the battery cell aging parameter, and $n$ is the sequence number. 


\subsection{Battery Cell Modeling and Settings}

In this electro-thermal modeling, the BESS is designed using a MATLAB Simulink environment ans simscape library, as shown in Figure 2. The designed HEV powertrain is developed for a passenger vehicle with a curb weight of $1600 \mathrm{~kg}$ which can travel up to $980 \mathrm{~km}$ (total range). Under positive acceleration a permanent magnet synchronous machine (PMSM) is employed to deliver a continuous torque between $0-450 \mathrm{Nm}$ and a maximum shaft speed of $10,000 \mathrm{rpm}$. A planetary gear with 2.8 gear ratio is selected to manage the power between the fuel engine with $120 \mathrm{~kW}$ maximum power and PMSM. In addition, a proportional and integral (PI) controller is used to control the speed at the proposition shaft in the drivetrain, and to study the aging of a lithium-ion $\left(\mathrm{LiFePO}_{4}\right)$ battery pack, the effects of different depth of discharge $(\mathrm{DoD})$, state of health $(\mathrm{SoH})$, capacity degradation, discharge current, $\mathrm{SoC}$, and $T_{a}$. As presented in Figure 2, the changes of positive (motoring) and negative (generating) accelerations from a standard Worldwide Harmonized Light Vehicle Test Procedure (WLTP) drive cycle [258] play an important role in battery charging and discharging bus currents.
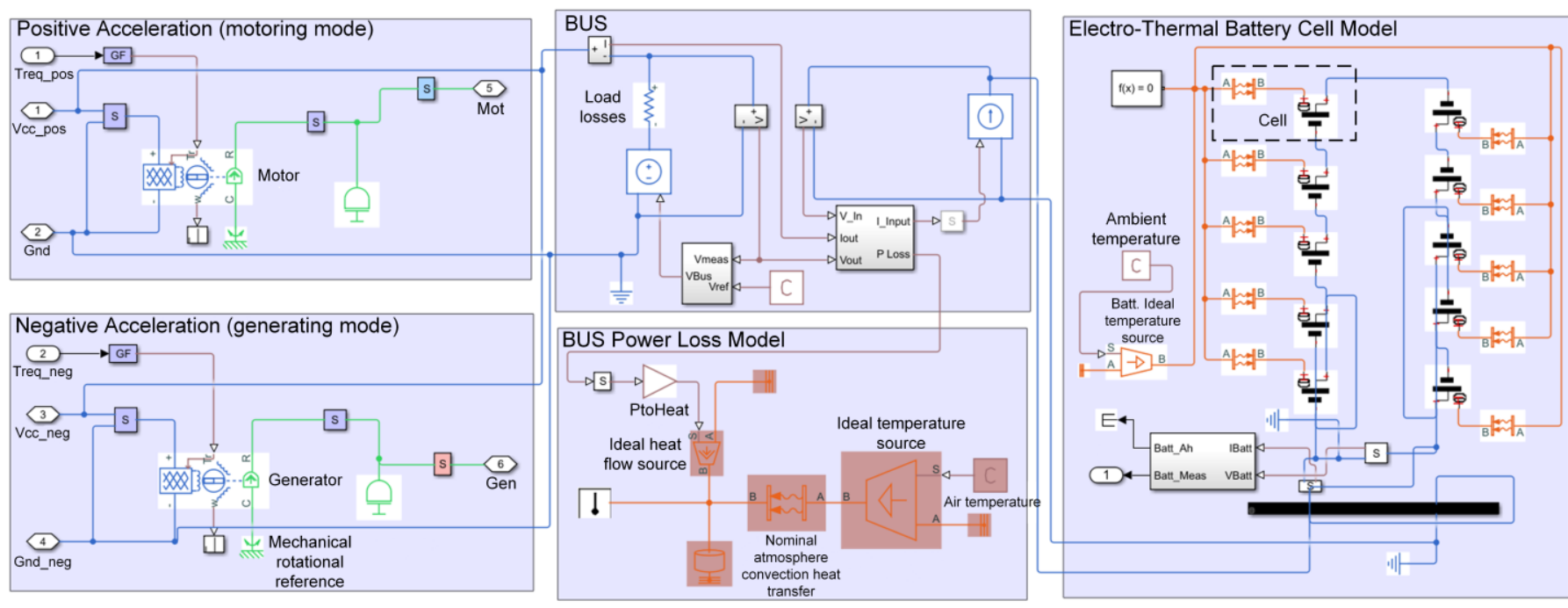

Figure 2. Electro-thermal model of lithium-ion battery cells, using MATLAB Simulink, for a passenger EV.

Figure 3 demonstrates the development of lithium-ion battery cells given in Figure 1. The model uses a simscape library from MATLAB Simulink, where multi-domain components (blue and orange lines indicate the electric and thermal connections physical system) are modeled. The selected solver is a variable-step type with an absolute tolerance of $1 \times 10^{-6}$, in which an adaptive zero-crossing algorithm is selected. Along with the battery cell's electrical components, such as resistors $R_{0}, R_{1}, R_{2}, R_{p}, E_{p}$, and $C_{1}$, other thermaloriented components like heat flow source, battery cell thermal mass, and sensors are utilized in this model. In the employed battery model, each cell contains an internal resistance of $R_{0}=0.0043 \Omega$, the main resistances of $R_{1}=1 \mathrm{~m} \Omega, R_{2}=0.1 \Omega$, and in the parasitic branch resistance of $R_{p}=2 e^{-11} \Omega^{-1}$, the main branch capacitance is $C_{1}=0.001 \mathrm{mF}$. The thermal model of each cell consists of a cell thermal mass of $400 \mathrm{~J} / \mathrm{kg} / \mathrm{K}$ which is inversely proportional to the heat flow rate in the cell. The output of the battery is connected to a DC/DC converter which also includes a thermal model to calculate the heat flow, and its associated power loss, via a convective heat transfer block. In this simulation, the average DC/DC converter temperature is $38^{\circ} \mathrm{C}$. The maximum DC bus voltage of $550 \mathrm{~V}$ and maximum battery voltage of $260 \mathrm{~V}$ is reported. Additionally, the ratio of ampere-hour capacity, $K_{t}(T)$, is a lookup table gathered at a standard time rate for a range of operating cell temperatures. The battery cell's specification is given in Table 6 . 


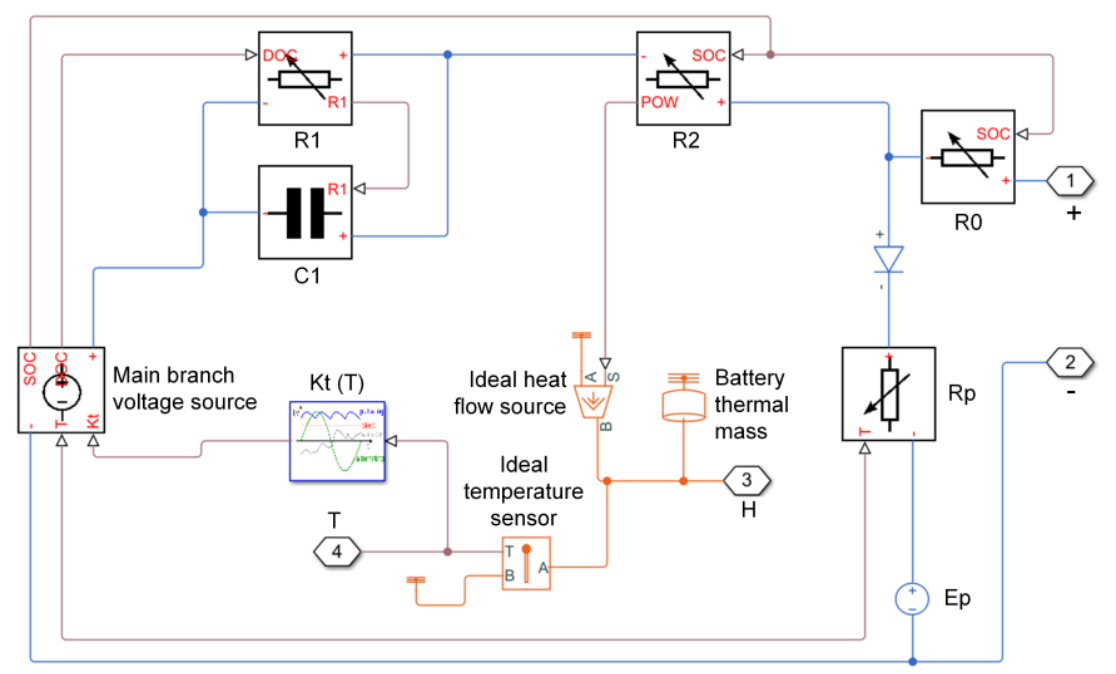

Figure 3. Electro-thermal battery cell model based on Thevenin circuit, in MATLAB Simulink environment.

Table 6. Lithium-ion battery cell specifications.

\begin{tabular}{ccc}
\hline Parameters & Value & Unit \\
\hline Rated capacity & 40 & $\mathrm{Ah}$ \\
Rated voltage & 12.8 & $\mathrm{~V}$ \\
Internal resistance at BoL & 0.0151 & $\Omega$ \\
Internal resistance at EoL & 0.0154 & $\Omega$ \\
Cut-off voltage & 10 & $\mathrm{~V}$ \\
Rated discharge current & 20 & $\mathrm{~A}$ \\
\hline
\end{tabular}

A quasi-Monte Carlo (QMC) simulation with Sobol sampling [259] is used for sensitivity analysis of several battery cell parameters to provide a simulation-based investigation on aging effects. The sensitivity analysis is done for $5000 \mathrm{~h}$ of driving using the WLTP drive cycle. Simulating QMC requires sampling generation through computed Sobol sensitivity indices. In this study, the sample number is 100 for every cell temperature from $25-55^{\circ} \mathrm{C}$. The sensitivity function $f(x)$ is defined as an $n$-dimensional unit hypercube, assuming $x^{u}$, as the $|u|$-dimensional vector, which contains variables $x_{j}$. Using analysis of variance (ANOVA) decomposition of $f(x)$, more details can be found in [260], each iteration computing as:

$$
f(x)=\sum_{u \subseteq(1, \ldots, n)} f_{u}\left(x^{u}\right)
$$

where the partial and total variance of $f(x)$ is given as:

$$
\left\{\begin{array}{c}
\sigma_{u}^{2}=\int_{[0,1]^{|u|}} f_{u}\left(x^{u}\right)^{2} d x^{u} \\
\sigma^{2}=\int_{[0,1]^{|n|}} f(x)^{2} d x^{u}-f_{\varnothing}^{2}
\end{array}\right.
$$

Based on Sobal's global sensitivity analysis, the indices to be calculated are:

$$
\left\{\begin{array}{c}
\underline{S}_{u}=\frac{1}{\sigma^{2}} \sum_{v \subseteq u} \sigma_{v}^{2} \\
\bar{S}_{u}=\frac{1}{\sigma^{2}} \sum_{v} \sigma_{u \neq \varnothing}^{2}
\end{array}\right.
$$


The aging simulations are successfully done using an Intel i7-9700 CPU at 3.00 GHz, with RAM of 32 GB and a 64-bit operating system. By using the parallel computing feature of MATLAB Simulink, each simulation took $450 \mathrm{~min}$.

\subsection{Results and Discussion}

A standard driving cycling profile is chosen to evaluate the life cycle of a $\mathrm{LiFePO}_{4}$ cell for EVs. The European Union (EU) has developed a new profile known as WLTP. This drive cycle has different average speeds such as low, medium, high, and extra high. The EU automobile industry welcomes the shift to WLTP and has actively contributed to developing this new test cycle. As a result of WLTP power demand, the simulations consist of a sequence of full charge and discharge cycles between the voltage limits of the battery cell.

The battery cell aging simulation allows characterizing cell temperature and degradation in-depth, providing the aging knee and thus offering useful information about the cell performance tested under the requested vehicle's power demand. The main parameters such as capacity, battery cell, and life cycles are presented for the total driving time of five hours.

Capacity degradation for five-hour performance is of considerable interest because of the impact of aging in batteries. Figure 4 demonstrates the variations of the equivalent cycle number and capacity, where the level of impact varies with the ambient temperature. The results show that the higher the ambient temperature, the higher the difference between BoL and EoL performance. For example, the life cycle varies between 1100-2500 for the range ambient temperature $\left(25-65^{\circ} \mathrm{C}\right)$ tested in this contribution. The capacity degradation between 43-31 can also be reported for corresponding ambient temperatures of $25-65{ }^{\circ} \mathrm{C}$. For this graph, high-dimensional datasets with 3,000,000 operating points were generated.

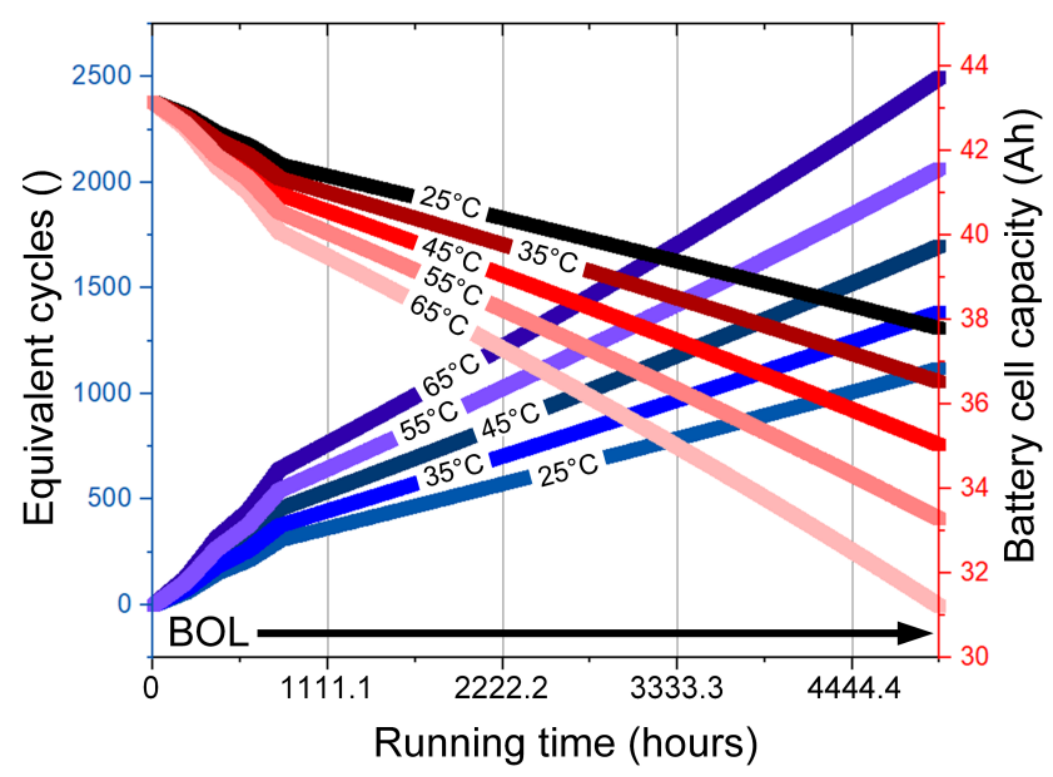

Figure 4. Equivalent cycles and battery cell capacity for a single lithium-ion battery cell considering ambient temperature.

In this case study, the electro-thermal system is primarily based on irreversible heat generation due to losses at the current collector and active cell materials. Also, the reversible heat production originates from an entropy change resulting from the intercalation and deintercalation of $\mathrm{LiFePO}_{4}$ cells. Figure 5 illustrates how the battery cell temperature varies depending on the charge and discharge current changes, which arise due to the power demand requested by the vehicle. The graph indicates that rationally higher cell temperatures occur when the discharge current is higher. Under the WLTP cycle, the cell temperature is mostly recorded below $65^{\circ} \mathrm{C}$. However, the highest is reported when both charging and discharging currents are very high, which happens during the major 
accelerations and decelerations, also known as harsh driving environments. Note that a natural air-cooling system is considered for generating this figure.

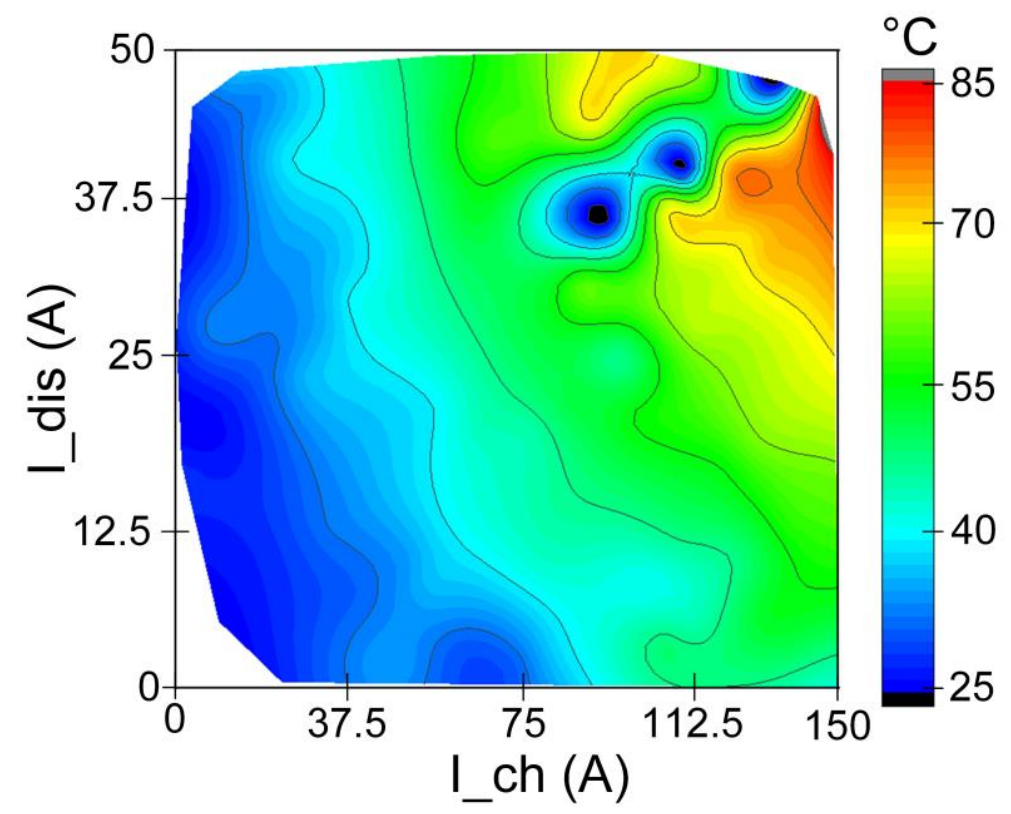

Figure 5. Lithium-ion battery cell temperature driven under WLTP drive cycle, using natural air cooling.

To better determine the impacts of charging and discharging requested currents, a global, randomized QMC sensitivity analysis was conducted (Figure 6). The different ambient temperatures eventually play a significant role in the battery cell operating temperature. For this simulation, 500 randomized samples were generated, where every 100 samples belong to one temperature category, e.g., 100 samples when the temperature remains $25^{\circ} \mathrm{C}$. The results explain how the maximum cycle number can substantially increase when the ambient temperature is higher. The dashed line area indicates the samples that critically suppress the battery cell capacity while the battery cell capacity falls between 1-10 Ah. Among them, most of the samples belong to $55-65^{\circ} \mathrm{C}$ cell temperature. The changes in both charging and discharging currents also affect the cycle number linearly until the aging knee. The aging knee light blue dashed line separates the samples into two regions. In the first region below the aging knee line, the battery cell's fading power capability is still linear; however, significant rises can be seen above the dashed line; primarily at the high charging and discharging bus currents. This cycle number increase mechanism is quantified based on the internal resistance increase (which is highly dependent on the cell operating temperature) and capacity loss. 


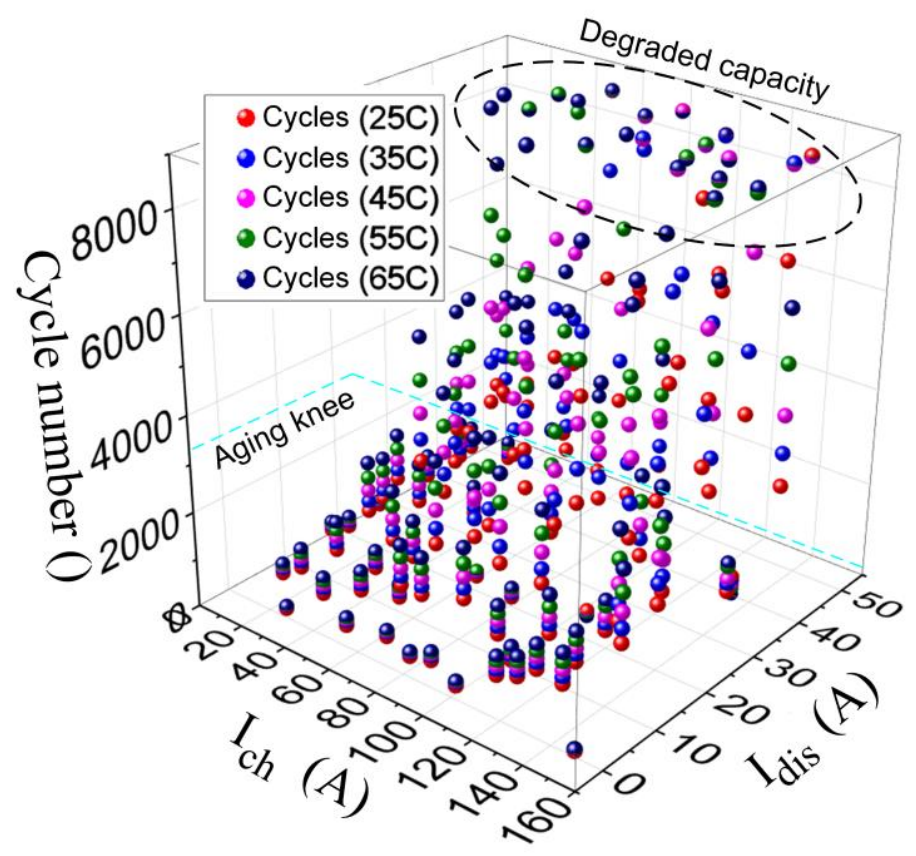

Figure 6. Lithium-ion battery cell life cycle as a functioning charging/discharging bus current, under WLTP drive cycle, using randomized samples in a QMC simulation.

\section{Potential and Future Prospects: A Prediction-Based Study on BESS for EVs}

The future trends of lithium-ion batteries for powering EVs are studied in this section. Based on the historic databases reported by [261], short-term, medium-range forecasts are presented using additive Winter's method. The fitting accuracy measurers are given:

$$
\left\{\begin{array}{c}
M A P E=\frac{1}{n} \sum_{t=1}^{n}\left|\frac{A_{t}-F_{t}}{A_{t}}\right| \\
M A D=\frac{1}{n} \sum_{i=1}^{n}\left|x_{i}-m(X)\right| \\
M S D=\frac{1}{n} \sum_{i=1}^{n}\left|x_{i}(t)-x_{i}(0)\right|^{2}
\end{array}\right.
$$

where MAPE is the mean absolute percentage error, $M A D$ is the mean absolute deviation, and $M S D$ is the mean squared displacement. $A_{t}$ is the actual value, $F_{t}$ is the forecast value, $n$ is the number of times the summation iteration occurred, and $x_{i}$ is the dataset vector where the $i$ subscript shows the data point number. $m(X)$ is the average value of the dataset. The $x_{i}(t)$ vector is the $i$ th data point at a time, and $x_{i}(0)$ is the $i$ th datapoint at the reference position. All the smoothing constants such as level, trend, and seasonal are selected to reduce the MAPE, MAD, and MSD outputs.

Figure 7 indicates the past, current, and future trends of worldwide growing lithiumion battery demand for light-duty and heavy-duty EVs. The historic data from 2009-2019 is provided by [261]. An additive winter method is used for future forecasting in this work. As presented in Figure 7a,c, the lithium-ion (capacity) market will increase by $11 \%$ and $65 \%$ between 2020-2025 for light-duty and heavy-duty EVs, respectively. The future short-term predictions show, in Figure $7 \mathrm{~b}, \mathrm{~d}$, that the lithium-ion equivalent in tons of cell mass will rise by $81 \%$ and $74 \%$ for both light-duty and heavy-duty EVs in the market between 2020-2025. As presented, the demand will significantly increase for lithium-ion-powered EVs globally. The results suggest that soon, the lithium-ion energy storage capacity for both lights- and heavy-duty electric vehicles is expected to double. This confirms the pattern identified by [262]. Therefore, in the current scenario, because of the higher demand for EVs, several lithium-ion batteries which need to be produced to sustain the development of the market are envisaged to grow quite significantly in the forthcoming years. Therefore, as suggested by [247], the system's capability to achieve large-scale deployment of ESSs will determine 
whether the automotive industry could satisfy the demand for electric vehicles. A significant increase in the manufacturing capacity will be required at different levels of the supply chain. This potential increase in the demand for storage capacity may reduce the cost of batteries due to the advantages arising from learning curves and economies of scale; as such, the increase can further boost the demand since battery packs are the most expensive component in an electrified drivetrain. Reducing their cost may thus allow EVs to become more affordable for more individuals. Therefore, the growth in EVs' demand could further contribute to this positive trend, accelerate the transition to e-mobility, and promote the adoption of electrified means of transport. However, the sharp increase in demand is not expected to last for a long period of time. The curve will reach the settling point as soon as most of the vehicles in circulation are dismissed and substituted by electric ones.

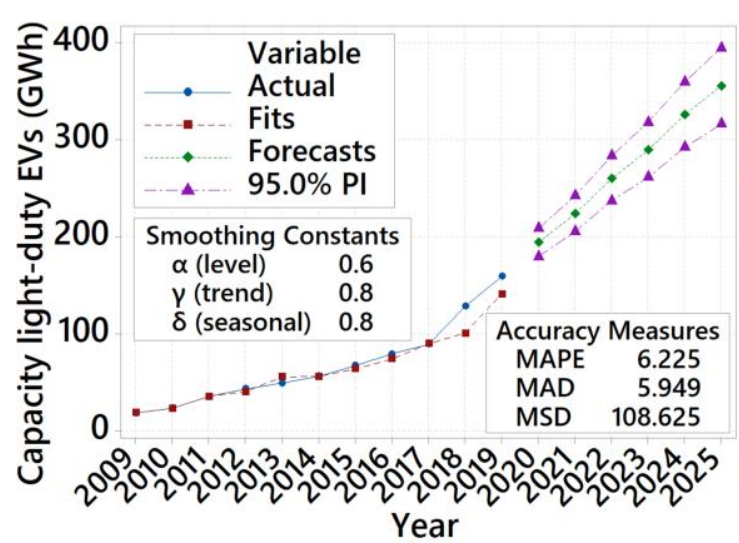

(a)

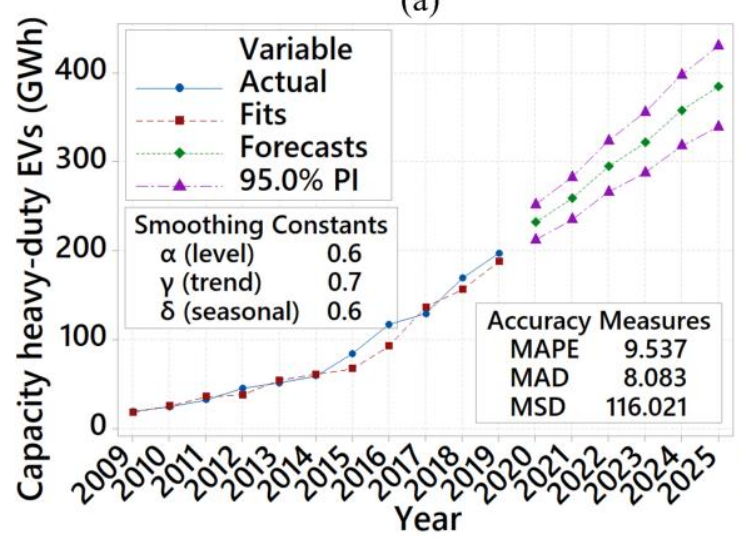

(c)

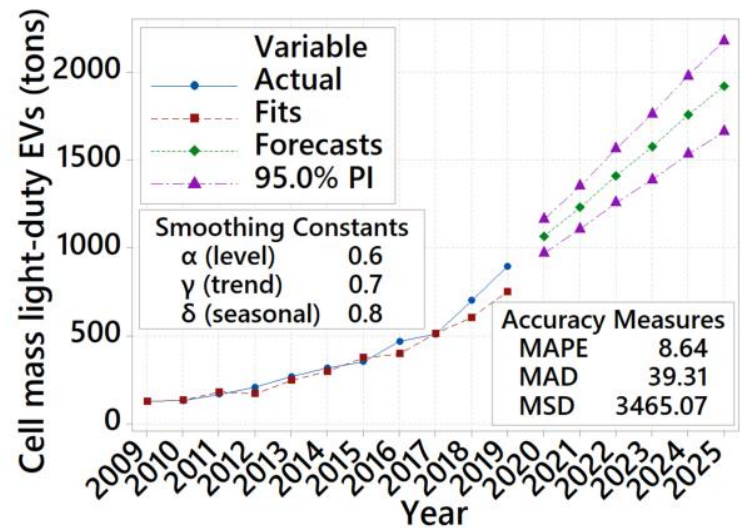

(b)

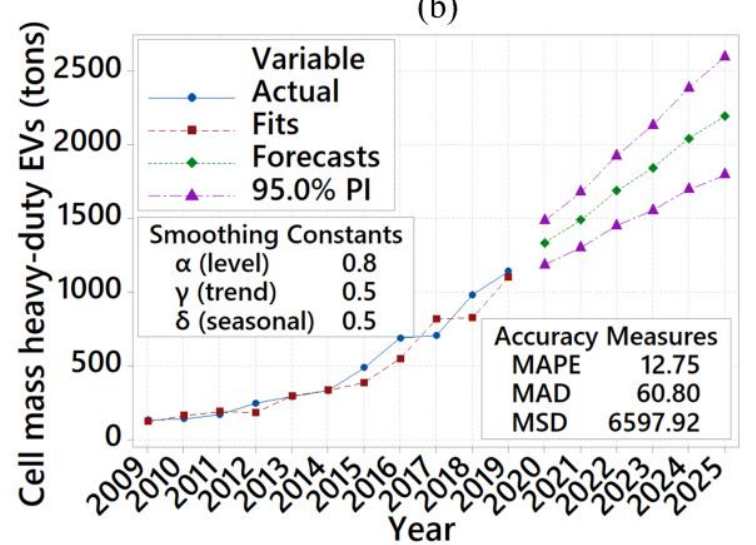

(d)

Figure 7. Future trends of lithium-ion battery capacity and cell mass production on the global market for EVs, where (a) capacity for light-duty EVs, (b) cell mass production for light-duty EVs only, (c) capacity for heavy-duty EVs, and (d) cell mass production for heavy-duty EVs. Note that 95\% Pl shows the lower and upper prediction limits for each forecast.

Figure 8 presents the expected demand for BEV and PHEV in different regions of the globe between 2020 and 2025. Historic data between 2010-2020 are provided in [247]. From the results obtained, the electric vehicle market will be characterized by a positive trend in different markets. Based on the predictions, the worldwide market will grow by about $140 \%$ up to 2025 . Europe is likely to experience an increase of approximately $103 \%$ and $110 \%$ in the sales for BEV and PHEV in the next five years. Once again, that implies that the number of vehicles sold in 2019 will more than double in five years. Similarly, the US demand will grow by approximately $135 \%$ for BEV and $114 \%$ for PHEV, almost tripling the 2019 recorded data. BEVs with a $110 \%$ increase and PHEVs with a $132 \%$ will observe a higher growth (increased percentage), but a lower total number of EVs in China, and other countries/regions, especially if the results are compared to the country's population. However, despite the difference in the adoption rate between different countries, the 
market size and the availability of financial support to purchase the vehicles, the number of vehicles sold will increase significantly considering the state of the art. There are reasons to believe that this trend is reinforced because of continuous government support to the transition to e-mobility. In fact, according to [247], environmental and sustainability objectives currently drive the policy framework, and more governments have announced strict measures to phase out traditional vehicles by $2050[247,263]$. However, the predicted growth of EVs may be hampered by potential bottlenecks caused by the finite availability of specialized materials required in battery manufacturing [264,265]. The natural scarcity of the critical material, the demand from competing sectors, the geographical concentration of resources, and the political instability of countries where resources are located pose a series of challenges for automotive supply chains due to the increase in supply disruption risk [266]. Therefore, future studies may assess whether production rates for material extraction and manufacturing could sustain the expansion of the electric vehicle market in different scenarios. In this context, it is paramount to consider battery aging patterns to improve the accuracy of the estimate in the battery demand and the number of necessary materials required.
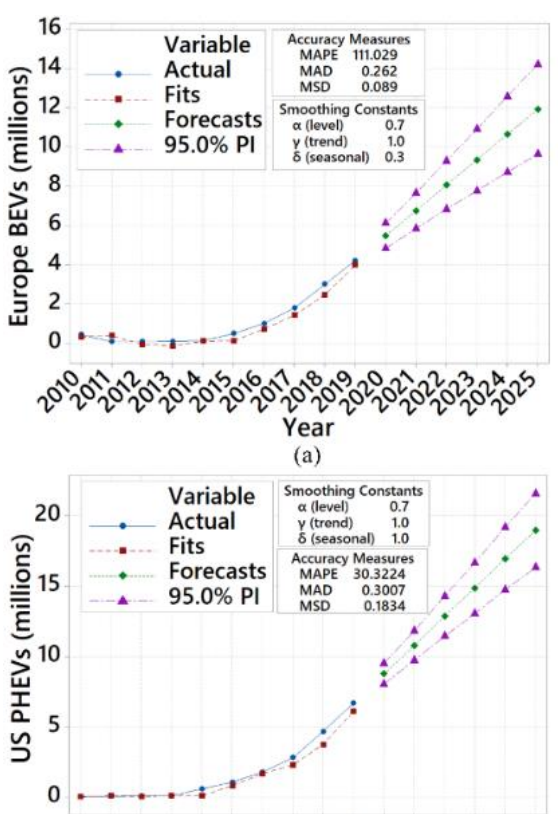

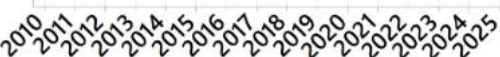

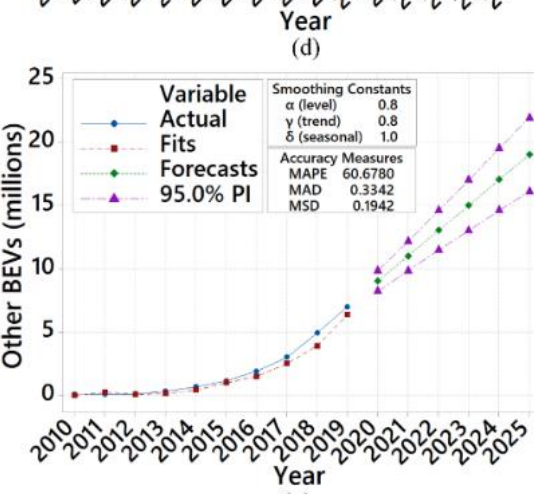

$(\mathrm{g})$
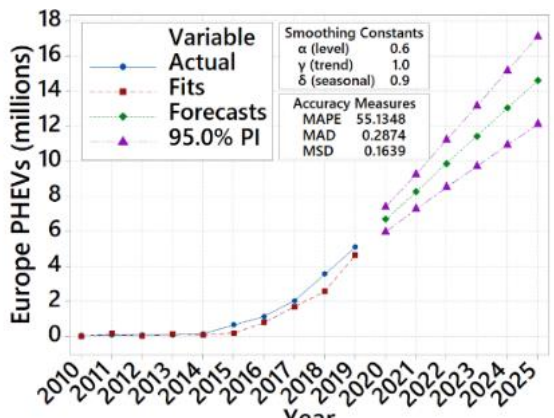

Year
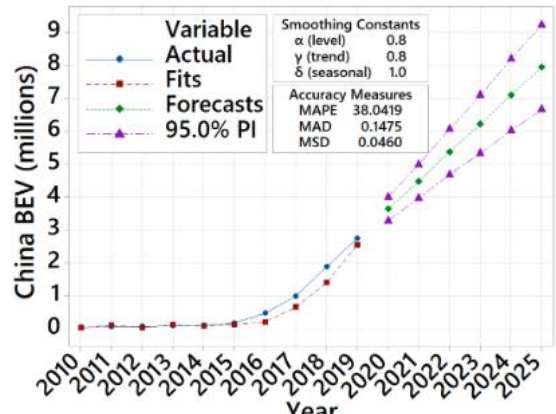

Year

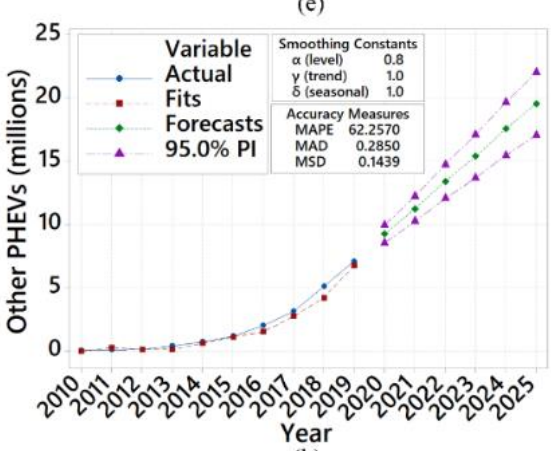

(h)
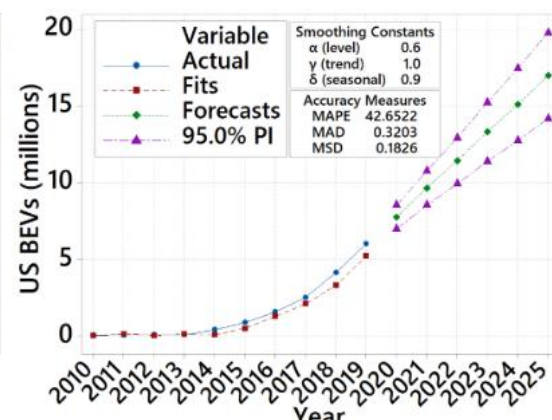

ear
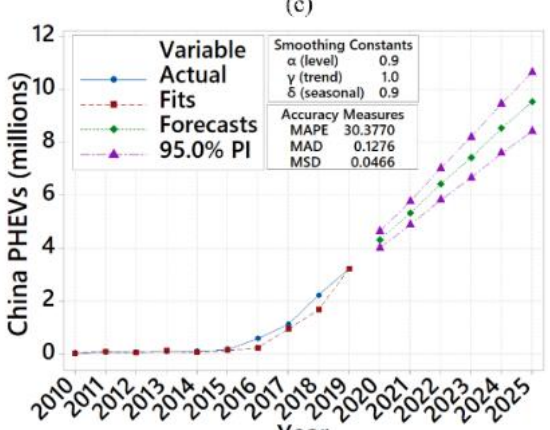

(f)

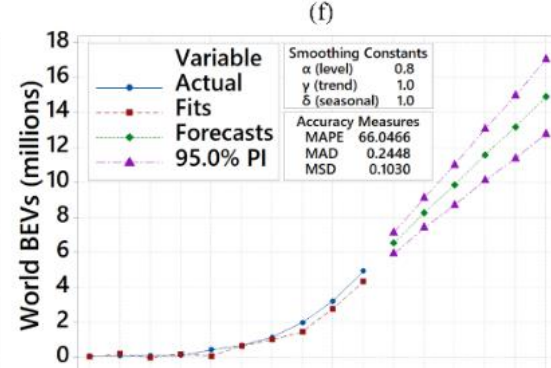

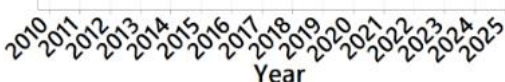

(i)

Figure 8. Future trends of BEV and PHEV market, using additive Winter's method, based on different regions (a) Europe BEVs, (b) Europe PHEVs, (c) US BEVs, (d) US PHEVS, (e) China BEVs, (f) China PHEVs, (g) Other BEVs, (h) Other PHEVs, and (i) World BEVs. Note that 95\% PI indicates lower and upper prediction limits. MAPE: Mean absolute percentage error; MAD: median absolute deviation; MSD: mean squared displacement. Note that $95 \% \mathrm{Pl}$ shows the lower and upper prediction limits for each forecast. 
Similarly, the availability, accessibility, and capability of public charging infrastructures may pose a threat to the large-scale adoption of BEVs, which could potentially revert this trend. Despite this, requirements for the charging facilities, including the optimal number of stations, locations, and charge schedules, are currently being investigated and countries are planning the development of infrastructure. Delays in developing solid private and public infrastructure could cause a severe setback and hinder the transition to the electrification of road transports. Further studies are required to explore barriers to the development of charging station infrastructures and their optimal integration in future transport, where the charging demand will be increasing significantly.

\section{Conclusions}

High-energy modern batteries are enabling EVs to drive farther on a single charge. The role of lithium-ion batteries is inevitable in the coming years, considering environmental issues such as the shortage and recycling of raw materials. These limitations stress the importance of the optimum selection and sizing of BESS. At the same time, battery size is estimated to increase by $80 \mathrm{kWh}$ to improve the range anxiety up to $400 \mathrm{~km}$ by 2030 . The supply of rare earth elements may become critical, such as lithium, cobalt, manganese, and nickel. Upon reviewing current research on battery-powered EVs, the main conclusions drawn are the following:

- Within the EV application operating temperature, the lithium-ion family batteries are, i.e., $\mathrm{LiMO}_{2}, \mathrm{LiMn}_{2} \mathrm{O}_{4}$, and $\mathrm{LiFePO}_{4}$. They are currently the best candidates because of their performance features, such as higher energy density, specific power, battery efficiency, and life cycle. Despite the technical suitability, such batteries may result in being more expensive compared to their alternatives. Therefore, advancements in battery technology or manufacturing processes are required to reduce their cost. $\mathrm{LiFePO}_{4}$ is the greenest and safest type; for instance, it does not produce oxygen, even when completely decomposed due to heating. The proposed batteries in terms of performance are $\mathrm{LiNi}_{1-\mathrm{x}-\mathrm{y}} \mathrm{Mn}_{\mathrm{x}} \mathrm{CoyO}_{2}$ because they can combine $\mathrm{LiCoO}_{2}$ and $\mathrm{LiNiO}_{2}$ and use much less Cobalt, making them safer.

- Among all modern rechargeable electromechanical batteries, the impact of temperature on capacity degradation and aging is unavoidable within the operation. For this reason, $\mathrm{NaNiCl}_{2}$ batteries have shown a greater thermal runaway range compared to other batteries. There is a gap in the literature on the thermal runaway of emerging lithium-ion batteries such as $\mathrm{LiNiCoAlO}_{2}, \mathrm{LiNi}_{\mathrm{x}} \mathrm{Mn}_{\mathrm{y}} \mathrm{Co}_{\mathrm{z}} \mathrm{O}_{2}$, and $\mathrm{LiCoO}_{2}$ cathodes.

- While the life cycle plays an important role in BESS design requirements, e.g., the US-advanced battery consortium defines a life cycle of 1000 cycles as one of the design requirements. In this paper, the aging effects and capacity degradation of a lithium-ion battery pack were investigated. Considering the battery cell temperature, the simulation-based study considered the HEV to operate for five hours driving under the WLTP drive cycle. The recorded results reported capacity fading of $18.42 \%$ between $25-65{ }^{\circ} \mathrm{C}$. The equivalent cycle number also rose by $19 \%$ for the same range of ambient temperature. Additionally, the impact of charging/discharging currents from the battery cell bus was presented using QMC simulations; the evaluations compared the increase of cycles required to finish the five-hour driving cycle. Higher temperatures resulted in a higher cycle number with consideration of the capacity fading.

- $\quad$ Based on the predictions using additive Winter's method, the growing global market of EVs will increase by $140 \%$ in 2025 . The lithium-ion market will increase by $11 \%$ and $65 \%$, between 2020-2025, for light-duty and heavy-duty EVs. The future short-term predictions also indicate that the lithium-ion cell production mass will rise by $81 \%$ and $74 \%$ for both light-duty and heavy-duty EVs in the market between 2020-2025.

- Based on the predictions in this study, the worldwide EV market will grow by approximately $140 \%$ up to 2025 . Europe is likely to experience an increase of approximately $103 \%$ and $110 \%$ million in the sales for BEV and PHEV in the next five years. That 
implies that the number of vehicles sold in 2019 will more than double in five years. Similarly, the US demand will grow by approximately $135 \%$ for BEV and $114 \%$ for PHEV, almost tripling the 2019 recorded data. BEVs with a $110 \%$ increase and PHEVs with a $132 \%$ increase will significantly grow in China, regardless of population density.

The aging analysis and other post-processing considerations play a critical role in an optimum, sustainable, and cost-effective transport system. Improving the effective life of electrochemical batteries can significantly replace environment-related detriments, reducing emissions and production costs of new batteries with recovering market supply chains and economic viability. While engineers and scientists are advancing the BESS's technology, more investigations are needed to ensure that this will not become a crucial environmental liability. Although EVs' positive environmental impacts are indisputable, there are a few raised challenges, such as recycling, damaging local effects of uncontrolled mining and refining, raw materials shortages (e.g., Cobalt), second-life battery utilization, charging station infrastructure, and potential supply/demand mismatch. Sustainable transport development is only reachable if all of these questions are answered, and further research is thus required.

Author Contributions: Conceptualization, P.A., M.M., A.L. and S.P.; methodology, P.A.; software, P.A.; validation, P.A., M.M., A.L. and S.P.; formal analysis, P.A.; investigation, P.A. and M.M.; resources, P.A.; data curation, P.A. and M.M.; writing—original draft preparation, P.A. and M.M; writing - review and editing, P.A., M.M., A.L. and S.P.; visualization, P.A.; supervision, P.A., M.M., A.L. and S.P.; project administration, P.A.; All authors have read and agreed to the published version of the manuscript.

Funding: Not applicable.

Institutional Review Board Statement: Not Applicable.

Informed Consent Statement: Not Applicable.

Data Availability Statement: Not Applicable.

Conflicts of Interest: The authors declare no conflict of interest.

\section{Nomenclature}

$\begin{array}{ll}\text { AC } & \text { Alternative current } \\ \text { BoL } & \text { Beginning of life } \\ \text { DoD } & \text { Depth of discharge } \\ \text { DC } & \text { Direct current } \\ \text { EV } & \text { Electric vehicle } \\ \text { EoL } & \text { End of life } \\ \text { ESS } & \text { Energy storage system } \\ \text { GHG } & \text { Greenhouse gas } \\ \text { HEV } & \text { Hybrid electric vehicle } \\ \text { PHEV } & \text { Plug-in hybrid electric vehicle } \\ \text { RUL } & \text { Remaining useful life } \\ \text { NiMH } & \text { Nickel-metal hybrid } \\ \text { SoC } & \text { State of charge } \\ \text { SoH } & \text { State of health } \\ \text { ICE } & \text { Internal combustion engine } \\ \text { BESS } & \text { Battery energy storage systems } \\ \text { ESS } & \text { Energy storage systems } \\ \text { BEV } & \text { Battery electric vehicle } \\ \text { LCA } & \text { Life cycle assessment } \\ \text { FB } & \text { Flow battery }\end{array}$




$\begin{array}{ll}\text { SB } & \text { Secondary battery } \\ \text { LA } & \text { Lead-acid } \\ \text { SLI } & \text { Starting, lighting, and ignition } \\ \text { UPS } & \text { Uninterruptible power supply } \\ \text { VRLA } & \text { Valve regulated lead-acid } \\ \text { AGM } & \text { Absorbent glass mat } \\ \text { WLTP } & \text { Worldwide harmonized light vehicle test procedure } \\ \text { QMC } & \text { Quasi-Monte Carlo } \\ \text { ANOVA } & \text { Analysis of variance } \\ \text { BoL } & \text { Beginning of life } \\ \text { EoL } & \text { End of life } \\ \text { MAPE } & \text { Mean absolute percentage error } \\ \text { MAD } & \text { Mean absolute deviation } \\ \text { MSD } & \text { Mean squared displacement }\end{array}$

\section{References}

1. Yasuoka, S.; Shuichi, D.; Imoto, Y.; Kai, T.; Yamazaki, T.; Ito, T.; Yano, T.; Takeno, K.; Yanagawa, H. Development of Highly Durable Ni-MH Batteries through Introduction of Highly Conductive Co Compound-Coated Ni(OH $)_{2}$ Technology. ECS Trans. 2015, 66, 19-27. [CrossRef]

2. Adams, S. Key Materials Challenges for Electrochemical Energy Storage Systems. Cosmos 2011, 7, 11-24. [CrossRef]

3. Sobianowska-Turek, A.; Urbańska, W.; Banaszkiewicz, K.; Lewko, P.; Marcinkowski, T.; Pasiecznik, I. Recovery of Ni, Cd and Co from spent nickel-cadmium (Ni-Cd) and nickel-metal hydride (Ni-MH) batteries by solvent extraction. Chem. Ind. 2020, $99,62-65$.

4. Wongrujipairoj, K.; Poolnapol, L.; Arpornwichanop, A.; Suren, S.; Kheawhom, S. Suppression of zinc anode corrosion for printed flexible zinc-air battery. Phys. Status Solidi 2016, 254, 1600442. [CrossRef]

5. Ershad, N.F.; Mehrjardi, R.; Ehsani, M. High-Performance 4WD Electric Powertrain with Flywheel Kinetic Energy Recovery. IEEE Trans. Power Electron. 2020, 36, 772-784. [CrossRef]

6. Islam, M.M.; Siffat, S.A.; Ahmad, I.; Liaquat, M.; Khan, S.A. Adaptive nonlinear control of unified model of fuel cell, battery, ultracapacitor and induction motor based hybrid electric vehicles. IEEE Access 2021, 9, 57486-57509. [CrossRef]

7. Lu, X.; Chen, Y.; Fu, M.; Wang, H. Multi-Objective Optimization-Based Real-Time Control Strategy for Battery/Ultracapacitor Hybrid Energy Management Systems. IEEE Access 2019, 7, 11640-11650. [CrossRef]

8. Acar, C.; Dincer, I. Better thermal management options with heat storage systems for various applications: An Evaluation. Energy Storage 2019, 1, e47. [CrossRef]

9. Tomoda, K.; Hoshi, N.; Haruna, J.; Cao, M.; Yoshizaki, A.; Hirata, K. Hydrolysis Rate Improvement in Hydrogen Generation System Fueled by Powdery Sodium Borohydride for Fuel-Cell Vehicle. IEEE Trans. Ind. Appl. 2013, 50, 2741-2748. [CrossRef]

10. Muhsen, H.; Al-Muhtady, A. Optimized modeling of Ni-MH batteries primarily based on Taguchi approach and evaluation of used Ni-MH batteries. Turk. J. Electr. Eng. Comput. Sci. 2019, 27, 197-212. [CrossRef]

11. Skvarenina, T. The Power Electronics Handbook; CRC Press: Boca Raton, FL, USA, 2002; p. 1664. ISBN 0849373360.

12. Mohammed, S.A.Q.; Jung, J.-W. A Comprehensive State-of-the-Art Review of Wired/Wireless Charging Technologies for Battery Electric Vehicles: Classification/Common Topologies/Future Research Issues. IEEE Access 2021, 9, 19572-19585. [CrossRef]

13. Naguib, M.; Kollmeyer, P.; Emadi, A. Lithium-Ion Battery Pack Robust State of Charge Estimation, Cell Inconsistency, and Balancing: Review. IEEE Access 2021, 9, 50570-50582. [CrossRef]

14. Metwly, M.Y.; Abdel-Majeed, M.S.; Abdel-Khalik, A.S.; Hamdy, R.A.; Hamad, M.S.; Ahmed, S. A Review of In-tegrated On-Board EV Battery Chargers: Advanced Topologies, Recent Developments and Optimal Selection of FSCW Slot/Pole Combination. IEEE Access 2020, 8, 85216-85242. [CrossRef]

15. Zhang, Y.; Nguyen, R.T.; Liaw, B. Status and Gap in Rechargeable Lithium Battery Supply Chain: Importance of Quantitative Failure Analysis. Proc. IEEE 2021, 109, 1029-1038. [CrossRef]

16. Duru, K.K.; Karra, C.; Venkatachalam, P.; Betha, S.A.; Madhavan, A.A.; Kalluri, S. Critical Insights into Fast Charging Techniques for Lithium-Ion Batteries in Electric Vehicles. IEEE Trans. Device Mater. Reliab. 2021, 21, 137-152. [CrossRef]

17. Vidal, C.; Malysz, P.; Kollmeyer, P.; Emadi, A. Machine Learning Applied to Electrified Vehicle Battery State of Charge and State of Health Estimation: State-of-the-Art. IEEE Access 2020, 8, 52796-52814. [CrossRef]

18. Lehtola, T.A.; Zahedi, A. Electric Vehicle Battery Cell Cycle Aging in Vehicle to Grid Operations: A Review. IEEE J. Emerg. Sel. Top. Power Electron. 2021, 9, 423-437. [CrossRef]

19. Pramanik, P.K.D.; Sinhababu, N.; Mukherjee, B.; Padmanaban, S.; Maity, A.; Upadhyaya, B.K.; Holm-Nielsen, J.B.; Choudhury, P. Power Consumption Analysis, Measurement, Management, and Issues: A State-of-the-Art Review of Smartphone Battery and Energy Usage. IEEE Access 2019, 7, 182113-182172. [CrossRef]

20. Sundin, D.W.; Sponholtz, S. Thermal Management of Li-Ion Batteries with Single-Phase Liquid Immersion Cooling. IEEE Open J. Veh. Technol. 2020, 1, 82-92. [CrossRef] 
21. Karlsen, H.; Dong, T.; Yang, Z.; Carvalho, R. Temperature-Dependence in Battery Management Systems for Electric Vehicles: Challenges, Criteria, and Solutions. IEEE Access 2019, 7, 142203-142213. [CrossRef]

22. Hannan, M.A.; Hoque, M.; Hussain, A.; Yusof, Y.; Ker, P.J. State-of-the-Art and Energy Management System of Lithium-Ion Batteries in Electric Vehicle Applications: Issues and Recommendations. IEEE Access 2018, 6, 19362-19378. [CrossRef]

23. Chemali, E.; Preindl, M.; Malysz, P.; Emadi, A. Electrochemical and Electrostatic Energy Storage and Management Systems for Electric Drive Vehicles: State-of-the-Art Review and Future Trends. IEEE J. Emerg. Sel. Top. Power Electron. 2016, 4, 1117-1134. [CrossRef]

24. Hossain, E.; Murtaugh, D.; Mody, J.; Faruque, H.M.R.; Sunny, S.H.; Mohammad, N. A Comprehensive Review on Second-Life Batteries: Current State, Manufacturing Considerations, Applications, Impacts, Barriers \& Potential Solutions, Business Strategies, and Policies. IEEE Access 2019, 7, 73215-73252. [CrossRef]

25. Omariba, B.Z.; Zhang, L.; Sun, D. Review of Battery Cell Balancing Methodologies for Optimizing Battery Pack Performance in Electric Vehicles. IEEE Access 2019, 7, 129335-129352. [CrossRef]

26. Xiong, R.; Cao, J.; Yu, Q.; He, H.; Sun, F. Critical Review on the Battery State of Charge Estimation Methods for Electric Vehicles. IEEE Access 2017, 6, 1832-1843. [CrossRef]

27. How, D.N.T.; Hannan, M.A.; Lipu, M.S.H.; Ker, P.J. State of Charge Estimation for Lithium-Ion Batteries Using Model-Based and Data-Driven Methods: A Review. IEEE Access 2019, 7, 136116-136136. [CrossRef]

28. Gao, Y.; Zhang, X.; Cheng, Q.; Guo, B.; Yang, J. Classification and Review of the Charging Strategies for Commercial Lithium-Ion Batteries. IEEE Access 2019, 7, 43511-43524. [CrossRef]

29. Vidal, C.; Gross, O.; Gu, R.; Kollmeyer, P.; Emadi, A. xEV Li-Ion Battery Low-Temperature Effects-Review. IEEE Trans. Veh. Technol. 2019, 68, 4560-4572. [CrossRef]

30. Dagnæs-Hansen, N.A.; Santos, F.I. Permanent magnet thrust bearings for flywheel energy storage systems: Analytical, numerical, and experimental comparisons. Proc. Inst. Mech. Eng. Part C J. Mech. Eng. Sci. 2019, 233, 5280-5293. [CrossRef]

31. El Mejdoubi, A.; Chaoui, H.; Gualous, H.; Bossche, P.V.D.; Omar, N.; Van Mierlo, J. Lithium-Ion Batteries Health Prognosis Considering Aging Conditions. IEEE Trans. Power Electron. 2019, 34, 6834-6844. [CrossRef]

32. Jafari, M.; Gauchia, A.; Zhang, K.; Gauchia, L. Simulation and Analysis of the Effect of Real-World Driving Styles in an EV Battery Performance and Aging. IEEE Trans. Transp. Electrif. 2015, 1, 391-401. [CrossRef]

33. Jafari, M.; Gauchia, A.; Zhao, S.; Zhang, K.; Gauchia, L. Electric Vehicle Battery Cycle Aging Evaluation in Real-World Daily Driving and Vehicle-to-Grid Services. IEEE Trans. Transp. Electrif. 2018, 4, 122-134. [CrossRef]

34. Gao, B.; Guo, L.; Zheng, Q.; Huang, B.; Chen, H. Acceleration Speed Optimization of Intelligent EVs in Consideration of Battery Aging. IEEE Trans. Veh. Technol. 2018, 67, 8009-8018. [CrossRef]

35. Liu, Z.; Onori, S.; Ivanco, A. Synthesis and Experimental Validation of Battery Aging Test Profiles Based on Real-World Duty Cycles for 48-V Mild Hybrid Vehicles. IEEE Trans. Veh. Technol. 2017, 66, 8702-8709. [CrossRef]

36. Uno, M.; Kukita, A. Cycle Life Evaluation Based on Accelerated Aging Testing for Lithium-Ion Capacitors as Alternative to Rechargeable Batteries. IEEE Trans. Ind. Electron. 2016, 63, 1607-1617. [CrossRef]

37. Kim, S.H.; Lee, H.M.; Shin, Y.-J. Aging Monitoring Method for Lithium-Ion Batteries Using Harmonic Analysis. IEEE Trans. Instrum. Meas. 2021, 70,1-11. [CrossRef]

38. Liu, K.; Li, Y.; Hu, X.; Lucu, M.; Widanage, W.D. Gaussian Process Regression with Automatic Relevance Determination Kernel for Calendar Aging Prediction of Lithium-Ion Batteries. IEEE Trans. Ind. Inform. 2020, 16, 3767-3777. [CrossRef]

39. Tang, X.; Liu, K.; Wang, X.; Gao, F.; Macro, J.; Widanage, W.D. Model Migration Neural Network for Predicting Battery Aging Trajectories. IEEE Trans. Transp. Electrif. 2020, 6, 363-374. [CrossRef]

40. She, C.; Wang, Z.; Sun, F.; Liu, P.; Zhang, L. Battery Aging Assessment for Real-World Electric Buses Based on Incremental Capacity Analysis and Radial Basis Function Neural Network. IEEE Trans. Ind. Inform. 2020, 16, 3345-3354. [CrossRef]

41. Vilsen, B.S.; Kær, K.S.; Stroe, I.D. Log-Linear Model for Predicting the Lithium-ion Battery Age Based on Resistance Extraction from Dynamic Aging Profiles. IEEE Trans. Ind. Appl. 2020, 56, 6937-6948. [CrossRef]

42. Vilsen, B.S.; Kær, K.S.; Stroe, I.D. Lithium-Ion Battery Health Prognosis Based on a Real Battery Management System Used in Electric Vehicles. IEEE Trans. Veh. Technol. 2019, 68, 4110-4121.

43. Corno, M.; Pozzato, G. Active Adaptive Battery Aging Management for Electric Vehicles. IEEE Trans. Veh. Technol. 2019, 69, 258-269. [CrossRef]

44. Chang, F.; Roemer, F.; Lienkamp, M. Influence of Current Ripples in Cascaded Multilevel Topologies on the Aging of Lithium Batteries. IEEE Trans. Power Electron. 2020, 35, 11879-11890. [CrossRef]

45. Sun, J.; Ma, Q.; Tang, C.; Wang, T.; Jiang, T.; Tang, Y. Research on Optimization of Charging Strategy Control for Aged Batteries. IEEE Trans. Veh. Technol. 2020, 69, 14141-14149. [CrossRef]

46. Casals, L.C.; García, B.A.; Aguesse, F.; Iturrondobeitia, A. Second life of electric vehicle batteries: Relation between materials degradation and environmental impact. Int. J. Life Cycle Assess. 2017, 22, 82-93. [CrossRef]

47. Faria, R.; Marques, P.; Moura, P.; Freire, F.; Delgado, J.; de Almeida, A.T. Impact of the electricity mix and use profile in the life-cycle assessment of electric vehicles. Renew. Sustain. Energy Rev. 2013, 24, 271-287. [CrossRef]

48. Hawkins, R.T.; Singh, B.; Majeau-Bettez, H.G.; Strømman, A. Comparative Environmental Life Cycle Assessment of Conventional and Electric Vehicles. J. Ind. Ecol. 2013, 17, 53-64. [CrossRef] 
49. Marques, P.; Garcia, R.; Kulay, L.; Freire, F. Comparative life cycle assessment of lithium-ion batteries for electric vehicles addressing capacity fade. J. Clean. Prod. 2019, 229, 787-794. [CrossRef]

50. Marques, P.; Garcia, R.; Freire, F. Life cycle assessment of electric and conventional cars in Portugal. In Proceedings of the Coference on Energy for Sustainability 2013, Sustainable Cities: Designing for People and the Planet, Coimbra, Portugal, 8-10 September 2013.

51. Freire, F.; Marques, P. Electric Vehicles in Portugal: An integrated energy, greenhouse gas and cost life-cycle analysis. In Proceedings of the IEEE International Symposium on Sustainable Systems and Technology (ISSST), Cincinnati, OH, USA, 15-17 May 2013; pp. 1-6.

52. Garcia, J.; Millet, D.; Tonnelier, P.; Richet, S.; Chenouard, R. A novel approach for global environmental performance evaluation of electric batteries for hybrid vehicles. J. Clean. Prod. 2017, 156, 406-417. [CrossRef]

53. Ma, Y.; Ke, R.-Y.; Han, R.; Tang, B.-J. The analysis of the battery electric vehicle's potentiality of environmental effect: A case study of Beijing from 2016 to 2020. J. Clean. Prod. 2017, 145, 395-406. [CrossRef]

54. Frischknecht, R.; Flury, K. Life cycle assessment of electric mobility: Answers and challenges. Int. J. Life Cycle Assess. 2011, 16, 691-695. [CrossRef]

55. Oliveira, L.; Messagie, M.; Rangaraju, S.; Sanfelix, J.; Rivas, M.H.; Van Mierlo, J. Key issues of lithium-ion batteries e from resource depletion to environmental performance indicators. J. Clean. Prod. 2015, 108, 354-362. [CrossRef]

56. Kushnir, D.; Sandén, B. The time dimension and lithium resource constraints for electric vehicles. Resour. Policy 2012, 37, 93-103. [CrossRef]

57. Lim, K.; Bastawrous, H.; Duong, V.-H.; See, K.; Zhang, P.; Dou, S.X. Fading Kalman filter-based real-time state of charge estimation in LiFePO4 battery-powered electric vehicles. Appl. Energy 2016, 169, 40-48. [CrossRef]

58. Wei, Z.; Meng, S.; Xiong, B.; Ji, D.; Tseng, K.J. Enhanced online model identification and state of charge estimation for lithium-ion battery with a FBCRLS based observer. Appl. Energy 2016, 181, 332-341. [CrossRef]

59. Yan, D.; Lu, L.; Li, Z.; Feng, X.; Ouyang, M.; Jiang, F. Durability comparison of four different types of high-power batteries in HEV and their degradation mechanism analysis. Appl. Energy 2016, 179, 1123-1130. [CrossRef]

60. Gradin, K.T.; Poulikidou, S.; Björklund, A.; Luttropp, C. Scrutinising the electric vehicle material backpack. J. Clean. Prod. 2018, 172, 1699-1710. [CrossRef]

61. Hasib, S.A.; Islam, S.; Chakrabortty, R.K.; Ryan, M.J.; Saha, D.K.; Ahamed, M.H.; Moyeen, S.I.; Das, S.K.; Ali, M.F.; Islam, M.R.; et al. A Comprehensive Review of Available Battery Datasets, RUL Prediction Approaches, and Advanced Battery Management. IEEE Access 2021, 9, 86166-86193. [CrossRef]

62. Vikström, H.; Davidsson, S.; Höök, M. Lithium availability and future production outlooks. Appl. Energy 2013, 110, 252-266. [CrossRef]

63. Park, S.; Salkuti, S.R. Optimal Energy Management of Railroad Electrical Systems with Renewable Energy and Energy Storage Systems. Sustainability 2019, 11, 6293. [CrossRef]

64. Linden, D.; Reddy, T. Handbook of Batteries; McGraw-Hill Professional Publishing: New York, NY, USA, 2001.

65. Wang, Z.-L.; Xu, D.; Xu, J.-J.; Zhang, X.-B. Oxygen electrocatalysts in metal-air batteries: From aqueous to nonaqueous electrolytes. Chem. Soc. Rev. 2014, 43, 7746-7786. [CrossRef]

66. Reddy, B.T. Linden's Handbook of Batteries, 4th ed.; McGrawHill: New York, NY, USA, 2011; ISBN 978-0-07-162419-0.

67. Parvini, Y.; Vahidi, A.; Fayazi, S.A. Heuristic Versus Optimal Charging of Supercapacitors, Lithium-Ion, and Lead-Acid Batteries: An Efficiency Point of View. IEEE Trans. Control Syst. Technol. 2017, 26, 167-180. [CrossRef]

68. Vulturescu, B.; Butterbach, S.; Forgez, C. Experimental Considerations on the Battery Lifetime of a Hybrid Power Source Made of Ultracapacitors and Lead-Acid Batteries. IEEE J. Emerg. Sel. Top. Power Electron. 2014, 2, 701-709. [CrossRef]

69. Zhang, B.; Guo, Z.; Zhao, Y.; Luo, B.; Li, D.; Zhao, T.; Sure, J.; Vishnu, S.M.; Abdelkader, A.; Harris, C.; et al. Effect of loading methods on the performance of hierarchical porous carbon/sulfur composites in lithium sulfur batteries. Electrochim. Acta 2021, 388,138650 . [CrossRef]

70. Fotouhi, A.; Auger, D.J.; Propp, K.; Longo, S.; Purkayastha, R.; O’Neill, L.; Walus, S. Lithium-Sulfur Cell Equivalent Circuit Network Model Parameterization and Sensitivity Analysis. IEEE Trans. Veh. Technol. 2017, 66, 7711-7721. [CrossRef]

71. Cai, Y.; Yan, Z.; Shi, S.; Zhang, L.; Zhang, T.; Yang, M.; Bai, L.; Fu, H.; Yang, X.S.; Li, Z.; et al. Titanium oxide nanowire clots with two-phase composition as multi-effect sulfur reservoirs for lithium-sulfur batteries. Scr. Mater. 2021, 202, 113989. [CrossRef]

72. Sun, W.; Li, Y.; Liu, S.; Liu, C.; Tan, X.; Xie, K. Mechanism investigation of iron selenide as polysulfide mediator for long-life lithium-sulfur batteries. Chem. Eng. J. 2021, 416, 129166. [CrossRef]

73. Stroe, D.I.; Knap, V.; Swierczynski, M.; Schaltz, E. Electrochemical Impedance Spectroscopy-Based Electric Circuit Modeling of Lithium-Sulfur Batteries During a Discharging State. IEEE Trans. Ind. Appl. 2019, 55, 631-637. [CrossRef]

74. Garapati, M.S.; Sundara, R. Enhancing polysulfide confinement and redox kinetics by electrocatalytic interlayer for highly stable lithium-sulfur batteries. Electrochim. Acta 2020, 362, 137035. [CrossRef]

75. Fotouhi, A.; Auger, J.D.; Propp, K.; Longo, S. Lithium-Sulfur Battery State-of-Charge Observability Analysis and Estimation. IEEE Trans. Power Electron. 2018, 33, 5847-5859. [CrossRef]

76. Gong, Z.; van de Ven, B.A.; Gupta, K.M.; da Silva, C.; Amon, C.H.; Bergveld, H.J.; Donkers, M.T.; Trescases, O. Distributed Control of Active Cell Balancing and Low-Voltage Bus Regulation in Electric Vehicles Using Hierarchical Model-Predictive Control. IEEE Trans. Ind. Electron. 2020, 67, 10464-10473. [CrossRef] 
77. Basic, H.; Pandzic, H.; Miletic, M.; Pavic, I. Experimental Testing and Evaluation of Lithium-Ion Battery Cells for a Special-Purpose Electric Vacuum Sweeper Vehicle. IEEE Access 2020, 8, 1-12.

78. Soares dos Santos, G.; José Grandinetti, F.; Augusto Rocha Alves, R.; de Queiróz Lamas, W. Design and Simulation of an Energy Storage System with Batteries Lead Acid and Lithium-Ion for an Electric Vehicle: Battery vs. Conduction Cycle Efficiency Analysis. IEEE Lat. Am. Trans. 2020, 18, 1345-1352. [CrossRef]

79. Xiong, R.; Tian, J.; Shen, W.; Sun, F. A Novel Fractional Order Model for State of Charge Estimation in Lithium-Ion Batteries. IEEE Trans. Veh. Technol. 2019, 68, 4130-4139. [CrossRef]

80. Yu, J. State-of-Health Monitoring and Prediction of Lithium-Ion Battery Using Probabilistic Indication and State-Space Model. IEEE Trans. on Instrum. Meas. 2015, 64, 2937-2949. [CrossRef]

81. Zhang, J.; Zhang, L.; Sun, F.; Wang, Z. An Overview on Thermal Safety Issues of Lithium-ion Batteries for Electric Vehicle Application. IEEE Access 2018, 6, 23848-23863. [CrossRef]

82. Xia, Z.; Qahouq, J.A.A. Lithium-Ion Battery Ageing Behavior Pattern Characterization and State-of-Health Estimation Using Data-Driven Method. IEEE Access. 2021, 9, 98287-98304. [CrossRef]

83. Zhang, X.; Peng, H.; Wang, H.; Ouyang, M. Hybrid Lithium Iron Phosphate Battery and Lithium Titanate Battery Systems for Electric Buses. IEEE Trans. Veh. Technol. 2017, 67, 956-965. [CrossRef]

84. Ai, S.; Mazumdar, S.; Li, H.; Cao, Y.; Li, T. Nano-silica doped Composite Polymer Chitosan/Poly(ethylene oxide)-Based Electrolyte with High Electrochemical Stability Suitable for Quasi Solid-state Lithium Metal Batteries. J. Electroanal. Chem. 2021, 895, 115464. [CrossRef]

85. Li, C.; Huang, Y.; Chen, C.; Feng, X.; Zhang, Z. High-performance polymer electrolyte membrane modified with isocyanate-grafted $\mathrm{Ti}^{3+}$ doped $\mathrm{TiO}_{2}$ nanowires for lithium batteries. Appl. Surf. Sci. 2021, 563, 150248. [CrossRef]

86. Lee, K.-P.; Gopalan, A.I.; Manesh, K.M.; Santhosh, P.; Kim, K.S. Influence of Finely Dispersed Carbon Nanotubes on the Performance Characteristics of Polymer Electrolytes for Lithium Batteries. IEEE Trans. Nanotechnol. 2007, 6, 362-367. [CrossRef]

87. Yuan, X.; Razzaq, A.A.; Chen, Y.; Lian, Y.; Zhao, X.; Peng, Y.; Deng, Z. Polyacrylonitrile-based gel polymer electrolyte filled with Prussian blue forhigh-performance lithium polymer batteries. Chin. Chem. Lett. 2021, 32, 890-894. [CrossRef]

88. Sun, M.; Zeng, Z.; Peng, L.; Han, Z.; Yu, C.; Cheng, S.; Xie, J. Ultrathin polymer electrolyte film prepared by in situ polymerization for lithium metal batteries. Mater. Today Energy 2021, 21, 100785. [CrossRef]

89. Makeen, P.; Ghali, H.A.; Memon, S. Experimental and Theoretical Analysis of the Fast Charging Polymer Lithium-Ion Battery Based on Cuckoo Optimization Algorithm (COA). IEEE Access 2020, 8, 140486-140496. [CrossRef]

90. Meng, J.; Luo, G.; Gao, F. Lithium Polymer Battery State-of-Charge Estimation Based on Adaptive Unscented Kalman Filter and Support Vector Machine. IEEE Trans. Power Electron. 2016, 31, 2226-2238. [CrossRef]

91. Lee, K.-T.; Dai, M.-J.; Chuang, C.-C. Temperature-Compensated Model for Lithium-Ion Polymer Batteries with Extended Kalman Filter State-of-Charge Estimation for an Implantable Charger. IEEE Trans. Ind. Electron. 2017, 65, 589-596. [CrossRef]

92. Antonucci, V.; Branchini, L.; Brunaccini, G.; De Pascale, A.; Ferraro, M.; Melino, F.; Orlandini, V.; Sergi, F. Thermal integration of a SOFC power generator and a Na-NiCl2 battery for CHP domestic application. Appl. Energy 2017, 185, 1256-1267. [CrossRef]

93. Heinz, M.V.; Graeber, G.; Landmann, D.; Battaglia, C. Pressure management and cell design in solid-electrolyte batteries, at the example of a sodium-nickel chloride battery. J. Power Sources 2020, 465, 228268. [CrossRef]

94. Braccoa, S.; Delfinoa, F.; Truccoa, A.; Zin, S. Electrical storage systems based on Sodium/Nickel chloride batteries: A mathematical model for the cell electrical parameter evaluation validated on a real smart microgrid application. J. Power Sources 2018, 399, 372-382. [CrossRef]

95. Wu, T.; Zhang, S.; Ao, X.; Wu, X.; Yang, J.; Wen, Z. Enhanced stability performance of nickel nanowire with 3D conducting network for planar sodium-nickel chloride batteries. J. Power Sources 2017, 360, 345-352. [CrossRef]

96. Sessa, S.D.; Palone, F.; Necci, A.; Benato, R. Sodium-nickel chloride battery experimental transient modelling for energy stationary storage. J. Energy Storage 2017, 9, 40-46. [CrossRef]

97. Sessa, S.D.; Crugnola, G.; Todeschini, M.; Zin, S.; Benato, R. Sodium nickel chloride battery steady-state regime model for stationary electrical energy storage. J. Energy Storage 2016, 6, 105-115. [CrossRef]

98. Lu, X.; Li, G.; Kim, Y.J.; Lemmon, P.J.; Sprenkle, L.V.; Yang, Z. The effects of temperature on the electrochemical performance of sodiumenickel chloride batteries. J. Power Sources 2012, 215, 288-295. [CrossRef]

99. Longo, S.; Antonucci, V.; Cellura, M.; Ferraro, M. Life cycle assessment of storage systems: The case study of a sodium/nickel chloride battery. J. Clean. Prod. 2014, 85, 337-346. [CrossRef]

100. Capasso, C.; Lauria, D.; Veneri, O. Experimental evaluation of model-based control strategies of sodium-nickel chloride battery plus supercapacitor hybrid storage systems for urban electric vehicles. Appl. Energy 2018, 228, 2478-2489. [CrossRef]

101. Shinde, N.M.; Shinde, P.V.; Yun, J.M.; Mane, R.S.; Kim, K.H. Room-temperature chemical synthesis of 3-D dandelion-type nickel chloride $\left(\mathrm{NiCl}_{2} @ \mathrm{NiF}\right)$ supercapattery nanostructured materials. J. Colloid Interface Sci. 2020, 578, 547-554. [CrossRef]

102. Chang, H.J.; Lu, X.; Bonnett, J.F.; Canfield, N.L.; Son, S.; Park, Y.-C.; Jung, K.; Sprenkle, V.L.; Li, G. Development of intermediate temperature sodium nickel chloride rechargeable batteries using conventional polymer sealing technologies. J. Power Sources 2017, 348, 150-157. [CrossRef]

103. Li, Y.; Shi, L.; Gao, X.; Wang, J.; Hu, Y.; Wu, X.; Wen, Z. Constructing a charged-state Na-NiCl2 battery with NiCl2/graphene aerogel composite as cathode. Chem. Eng. J. 2021, 421, 127853. [CrossRef] 
104. Kumar, D.; Rajouria, S.K.; Kuhar, S.B.; Kanchan, D. Progress and prospects of sodium-sulfur batteries: A review. Solid State Ionics 2017, 312, 8-16. [CrossRef]

105. Syali, M.S.; Kumar, D.; Mishra, K.; Kanchan, D. Recent advances in electrolytes for room-temperature sodium-sulfur batteries: A review. Energy Storage Mater. 2020, 31, 352-372. [CrossRef]

106. Kumar, V.; Eng, A.Y.S.; Wang, Y.; Nguyen, D.-T.; Ng, M.-F.; Seh, Z.W. An artificial metal-alloy interphase for high-rate and long-life sodium-sulfur batteries. Energy Storage Mater. 2020, 29, 1-8. [CrossRef]

107. Wang, H.; Deng, C.; Li, X.; Yan, D.; Xie, M.; Zhang, S.; Huang, B. Designing dual-defending system based on catalytic and kinetic iron Pyrite@C hybrid fibers for long-life room-temperature sodium-sulfur batteries. Chem. Eng. J. 2021, 420, 129681. [CrossRef]

108. Wan, H.; Weng, W.; Han, F.; Cai, L.; Wang, C.; Yao, X. Bio-inspired Nanoscaled Electronic/Ionic Conduction Networks for Room-Temperature All-Solid-State Sodium-Sulfur Battery. Nano Today 2020, 33, 100860. [CrossRef]

109. Yang, J.-Y.; Han, H.-J.; Repich, H.; Zhi, R.-C.; Qu, C.-Z.; Kong, L.; Kaskel, S.; Wang, H.-Q.; Xu, F.; Li, H.-J. Recent progress on the design of hollow carbon spheres to host sulfur in room-temperature sodium-sulfur batteries. New Carbon Mater. 2020, 35, 630-645. [CrossRef]

110. Galushkin, N.E.; Yazvinskaya, N.N.; Galushkin, D.N. Nickel-cadmium batteries with pocket electrodes as hydrogen energy storage units of high-capacity. J. Energy Storage 2021, 39, 102597. [CrossRef]

111. Basant, N.; Singh, J.; Kumari, B.; Sinam, G.; Gautam, A.; Singh, G.; Mishra, K.; Mallick, S. Nickel and cadmium phytoextraction efficiencies of vetiver and lemongrass grown on $\mathrm{Ni}-\mathrm{Cd}$ battery waste contaminated soil: A comparative study of linear and nonlinear models. J. Environ. Manag. 2021, 295, 113144. [CrossRef]

112. Paul, S.; Shakya, A.K.; Ghosh, P.K. Bacterially-assisted recovery of cadmium and nickel as their metal sulfide nanoparticles from spent Ni-Cd battery via hydrometallurgical route. J. Environ. Manag. 2020, 261, 110113. [CrossRef]

113. Rahangdale, D.; Kumar, A. Acrylamide grafted chitosan based ion imprinted polymer for the recovery of cadmium from nickel-cadmium battery waste. J. Environ. Chem. Eng. 2018, 6, 1828-1839. [CrossRef]

114. Pourabdollah, K. Development of electrolyte inhibitors in nickel cadmium batteries. Chem. Eng. Sci. 2017, 160, 304-312. [CrossRef]

115. Espinosa, D.C.R.; Tenório, J.A.S. Recycling of nickel-cadmium batteries using coal as reducing agent. J. Power Sources 2006, 157, 600-604. [CrossRef]

116. Norian, K. Equivalent circuit components of nickel-cadmium battery at different states of charge. J. Power Sources 2011, 196, 5205-5208. [CrossRef]

117. Tang, H.; Sun, Z.; Chang, K.; Hou, Y.; Li, B.; Hou, Y.; Chang, Z. Uniform carbon coating drastically enhances the electro-chemical performance of $\mathrm{Fe}_{3} \mathrm{O}_{4}$ electrode for alkaline nickel-iron rechargeable batteries. Int. J. Hydrogen Energy 2019, 44, 24895-24904. [CrossRef]

118. Pramanik, A.; Maiti, S.; Chattopadhyay, S.; De, G.; Mahanty, S. ‘Cotton-ball' shaped porous iron-nickel sulfide: A high-rate cathode for long-life aqueous rechargeable battery. Mater. Res. Bull. 2021, 140, 111307. [CrossRef]

119. Tang, H.; Zhang, C.; Chang, K.; Shangguan, E.; Li, B.; Chang, Z. Synthesis of NiS coated Fe3O4 nanoparticles as high-performance positive materials for alkaline nickel-iron rechargeable batteries. Int. J. Hydrogen Energy 2017, 42, 24939-24947. [CrossRef]

120. Guo, C.; Li, C.M. Molecule-confined FeOx nanocrystals mounted on carbon as stable anode material for high energy density nickel-iron batteries. Nano Energy 2017, 42, 166-172. [CrossRef]

121. Li, J.; Wang, S.; Chen, X.; Xiao, T.; Tan, X.; Xiang, P.; Jiang, L. Enhancing electrochemical performance of $\mathrm{Fe}_{2} \mathrm{O}_{3}$ via in situ sulfurization and carbon coating modification for nickel-iron rechargeable batteries. Electrochim. Acta 2018, 290, 332-338. [CrossRef]

122. Zhi, H.; Ni, S.; Su, X.; Xie, W.; Zhang, H.; Sun, X. Separation and recovery of rare earth from waste nickel-metal hydride batteries by phosphate based extraction-precipitation. J. Rare Earths 2021, 1-26. [CrossRef]

123. Wang, W.; Liu, X.; Zhang, L.; Zhang, S.; Guo, W.; Zhao, Y.; Zhang, H.; Li, Y.; Han, S. The electrochemical characteristics of AB4-type rare earth-Mg-Ni-based superlattice structure hydrogen storage alloys for nickel metal hydride battery. J. Magnes. Alloys 2021, 1-10. [CrossRef]

124. Odegbemi, F.; Idowu, G.A.; Adebayo, A.O. Nickel recovery from spent nickel-metal hydride batteries using LIX-84I-impregnated activated charcoal. Environ. Nanotechnol. Monit. Manag. 2021, 15, 100452. [CrossRef]

125. Li, M.; Wang, C.; Yang, C. Development of high-performance hydrogen storage alloys for applications in nickel-metal hydride batteries at ultra-low temperature. J. Power Sources 2021, 491, 229585. [CrossRef]

126. Vargas, S.J.; Schaeffer, N.; Souza, J.C.; da Silva, L.H.; Hespanhol, M.C. Green separation of lanthanum, cerium and nickel from waste nickel metal hydride battery. Waste Manag. 2021, 125, 154-162. [CrossRef] [PubMed]

127. Wang, W.; Xu, G.; Zhang, L.; Ma, C.; Zhao, Y.; Zhang, H.; Ding, Z.; Fu, Y.; Li, Y.; Han, S. Electrochemical features of Ce ${ }_{2} \mathrm{Ni}_{7}$-type $\mathrm{La}_{0.65} \mathrm{Nd}_{0.15} \mathrm{Mg}_{0.25} \mathrm{Ni}_{3.20} \mathrm{M}_{0.10}(\mathrm{M}=\mathrm{Ni}, \mathrm{Mn}$ and $\mathrm{Al})$ hydrogen storage alloys for rechargeable nickel metal hydride battery. $J$. Alloys Compd. 2021, 861, 158469. [CrossRef]

128. Wang, W.; Qin, R.; Wu, R.; Tao, X.; Zhang, H.; Ding, Z.; Fu, Y.; Zhang, L.; Wu, L.; Li, Y.; et al. A promising anode candidate for rechargeable nickel metal hydride power battery: An A5B19-type La-Sm-Nd-Mg-Ni-Al-based hydrogen storage alloy. J. Power Sources 2020, 465, 228236. [CrossRef]

129. Ding, J.; Zheng, H.; Gao, H.; Wang, S.; Wu, S.; Fang, S.; Cheng, F. Operando non-topological conversion constructing the high-performance nickel-zinc battery anode. Chem. Eng. J. 2021, 414, 128716. [CrossRef] 
130. Cheng, Y.; Guo, H. Interface modification of electrodes through polyethylene glycol in rechargeable zinc-nickel batteries. Chem. Eng. Sci. 2020, 232, 116372. [CrossRef]

131. Yuan, L.; Yang, Z.; Cui, F.; Rong, Y.; Su, Q.; Chen, H.; Wu, J.; Deng, L. Flower-like Zn-Al-In layered double oxides synthesized by a facile hydrothermal method as ultra-high cycle stability anodic for zinc-nickel battery. J. Alloys Compd. 2021, 863, 158574. [CrossRef]

132. Wei, J.S.; Zhu, Z.Y.; Zhao, X.; Song, T.B.; Huang, J.H.; Zhang, Y.X.; Liu, X.; Chen, L.; Niu, X.Q.; Wang, Y.G.; et al. Self-assembled ZnO-carbon dots anode materials for high performance nickel-zinc alkaline batteries. Chem. Eng. J. 2021, 425, 130660. [CrossRef]

133. Cui, F.; Yang, Z.; Chen, L.; Zeng, X.; Meng, J.; Jiang, Y. Preparation of spherical carbonated foam/Zn-Al layered double oxides composite anode and its superior cycling stability in Zinc-Nickel secondary batteries. J. Power Sources 2021, $500,229957$. [CrossRef]

134. Zhu, X.; Wu, Y.; Lu, Y.; Sun, Y.; Wu, Q.; Pang, Y.; Shen, Z.; Chen, H. Aluminum-doping-based method for the improvement of the cycle life of cobalt-nickel hydroxides for nickel-zinc batteries. J. Colloid Interface Sci. 2021, 587, 693-702. [CrossRef] [PubMed]

135. Li, S.; Li, K.; Xiao, E.; Zhang, J.; Zheng, M. Real-time peak power prediction for zinc nickel single flow batteries. J. Power Sources 2020, 448, 227346. [CrossRef]

136. Wang, C.; Li, J.; Zhou, Z.; Pan, Y.; Yu, Z.; Pei, Z.; Zhao, S.; Wei, L.; Chen, Y. Rechargeable zinc-air batteries with neutral electrolytes: Recent advances, challenges, and prospects. EnergyChem 2021, 3, 100055. [CrossRef]

137. Hosseini, S.; Soltani, S.M.; Li, Y.-Y. Current status and technical challenges of electrolytes in zinc-air batteries: An in-depth review. Chem. Eng. J. 2021, 408, 127241. [CrossRef]

138. Wei, H.-L.; Tan, A.-D.; Hu, S.-Z.; Piao, J.-H.; Fu, Z.-Y. Efficient spinel iron-cobalt oxide/nitrogen-doped ordered mesoporous carbon catalyst for rechargeable zinc-air batteries. Chin. J. Catal. 2021, 42, 1451-1458. [CrossRef]

139. Mainar, A.R.; Iruin, E.; Blázquez, J.A. High performance secondary zinc-air/silver hybrid battery. J. Energy Storage 2021, 33, 102103. [CrossRef]

140. Xu, L.; Wu, S.; Deng, D.; Wang, C.; Qian, J.; Lu, G.; Li, H. Fabricating highly active and stable tungsten carbide electrocatalyst for rechargeable zinc-air batteries: An approach of dual metal Co-adjusted the electronic structure. J. Alloys Compd. 2021, 868, 159236. [CrossRef]

141. Yu, W.; Shang, W.; Xiao, X.; Ma, Y.; Chen, Z.; Chen, B.; Xu, H.; Ni, M.; Tan, P. Elucidating the mechanism of discharge performance improvement in zinc-air flow batteries: A combination of experimental and modeling investigations. J. Energy Storage 2021, 40, 102779. [CrossRef]

142. Logeshwaran, N.; Ramakrishnan, S.; Chandrasekaran, S.S.; Vinothkannan, M.; Kim, A.R.; Sengodan, S.; Velusamy, D.B.; Varadhan, P.; He, J.-H.; Yoo, D.J. An efficient and durable trifunctional electrocatalyst for zinc-air batteries driven overall water splitting. Appl. Catal. B: Environ. 2021, 297, 120405. [CrossRef]

143. Pan, L.; Chen, D.; Pei, P.; Huang, S.; Ren, P.; Song, X. A novel structural design of air cathodes expanding three-phase reaction interfaces for zinc-air batteries. Appl. Energy 2021, 290, 116777. [CrossRef]

144. Gao, L.; Li, Z.; Zou, Y.; Yin, S.; Peng, P.; Shao, Y.; Liang, X. A High-Performance Aqueous Zinc-Bromine Static Battery. iScience 2020, 23, 101348. [CrossRef]

145. Xu, P.; Li, T.; Zheng, Q.; Zhang, H.; Yin, Y.; Li, X. A low-cost bromine-fixed additive enables a high capacity retention zinc-bromine batteries. J. Energy Chem. 2021, 65, 89-93. [CrossRef]

146. Xu, Z.; Fan, Q.; Li, Y.; Wang, J.; Lund, P.D. Review of zinc dendrite formation in zinc bromine redox flow battery. Renew. Sustain. Energy Rev. 2020, 127, 109838. [CrossRef]

147. Wu, M.; Zhang, R.; Liu, K.; Sun, J.; Chan, K.; Zhao, T. Mesoporous carbon derived from pomelo peel as a high-performance electrode material for zinc-bromine flow batteries. J. Power Sources 2019, 442, 227255. [CrossRef]

148. Archana, K.S.; Naresh, R.P.; Enale, H.; Rajendran, V.; Mohan, A.M.V.; Bhaskar, A.; Ragupathy, P.; Dixon, D. Effect of positive electrode modification on the performance of zinc-bromine redox flow batteries. J. Energy Storage 2020, 29, 101462. [CrossRef]

149. Jin, C.X.; Lei, H.Y.; Liu, M.Y.; Tan, A.D.; Piao, J.H.; Fu, Z.Y.; Liang, Z.X.; Wang, H.H. Low-dimensional nitrogen-doped carbon for $\mathrm{Br}_{2} / \mathrm{Br}_{-}$redox reaction in zinc-bromine flow battery. Chem. Eng. J. 2020, 380, 122606. [CrossRef]

150. Wu, M.C.; Zhao, T.S.; Wei, L.; Jiang, H.R.; Zhang, R.H. Improved electrolyte for zinc-bromine flow batteries. J. Power Sources 2018, 384, 232-239. [CrossRef]

151. Yu, F.; Pang, L.; Wang, X.; Waclawik, E.R.; Wang, F.; Ostrikov, K.; Wang, H. Aqueous alkaline-acid hybrid electrolyte for zinc-bromine battery with $3 \mathrm{~V}$ voltage window. Energy Storage Mater. 2019, 19, 56-61. [CrossRef]

152. Lai, Q.; Zhang, H.; Li, X.; Zhang, L.; Cheng, Y. A novel single flow zinc-bromine battery with improved energy density. J. Power Sources 2013, 235, 1-4. [CrossRef]

153. Shimin, Z. Investigation of the charge/discharge characteristics of aqueous zinc-ferric chloride batteries. J. Power Sources 2006, 160, 1442-1446. [CrossRef]

154. Deyab, A.M. Hydroxyethyl cellulose as efficient organic inhibitor of zincecarbon battery corrosion in ammonium chloride solution: Electrochemical and surface morphology studies. J. Power Sources 2015, 280, 190-194. [CrossRef]

155. Jugovic, Z.B.; Trisovi, L.T.; Stevanovic, J.S.; Maksimovic, M.D.; Grgur, N.B. Comparative studies of chloride and chloride/citratebased electrolytes for zinc-polyaniline batteries. Electrochim. Acta 2006, 51, 6268-6274. [CrossRef]

156. Ji, L.; Zhang, X. Generation of activated carbon nanofibers from electrospun polyacrylonitrile-zinc chloride composites for use as anodes in lithium-ion batteries. Electrochem. Commun. 2009, 11, 684-687. [CrossRef] 
157. Borchers, N.; Clark, S.; Horstmann, B.; Jayasayee, K.; Juel, M.; Stevens, P. Innovative zinc-based batteries. J. Power Sources 2021, 484, 229309. [CrossRef]

158. Kar, M.; Gonzalo, C.P. Emergence of nonaqueous electrolytes for rechargeable zinc batteries. Curr. Opin. Green Sustain. Chem. 2021, 28, 100426. [CrossRef]

159. Zhao, S.; An, H.; Chen, S. A study of a high-power, ammonium chloride zinc/manganese dioxide dry battery. J. Power Sources 1998, 76, 218-220. [CrossRef]

160. Hu, L.; Xiao, P.; Xue, L.; Li, H.; Zhai, T. The rising zinc anodes for high-energy aqueous batteries. EnergyChem $2021,3,100052$. [CrossRef]

161. Wang, S.; Yuan, C.; Chang, N.; Song, Y.; Zhang, H.; Yin, Y.; Li, X. Act in contravention: A non-planar coupled electrode design utilizing "tip effect" for ultra-high areal capacity, long cycle life zinc-based batteries. Sci. Bull. 2021, 66, 889-896. [CrossRef]

162. Samadani, E.S.; Fraser, A.R.; Fowler, M. A Review Study of Methods for Lithium-Ion Battery Health Monitoring and Remaining Life Estimation in Hybrid Electric Vehicles; SAE Int.: Warrendale, PA, USA, 2012.

163. Pattipati, B.; Sankavaram, C.; Pattipati, K. System Identification and Estimation Framework for Pivotal Automotive Battery Management System Characteristics. IEEE Trans. Syst. Man Cybern. Part C Appl. Rev. 2011, 41, 869-884. [CrossRef]

164. Feng, X.; Ouyang, M.; Liu, X.; Lu, L.; Xia, Y.; He, X. Thermal runaway mechanism of lithium ion battery for electric vehicles: A review. Energy Storage Mater. 2018, 10, 246-267. [CrossRef]

165. Lin, X.; Kim, Y.; Mohan, S.; Siegel, J.B.; Stefanopoulou, A.G. Modeling and Estimation for Advanced Battery Management. Annu. Rev. Control Robot. Auton. Syst. 2019, 2, 393-426. [CrossRef]

166. Ahmed, R.; El Sayed, M.; Arasaratnam, I.; Tjong, J.; Habibi, S. Reduced-Order Electrochemical Model Parameters Identification and State of Charge Estimation for Healthy and Aged Li-Ion Batteries-Part II: Aged Battery Model and State of Charge Estimation. IEEE J. Emerg. Sel. Top. Power Electron. 2014, 2, 678-690. [CrossRef]

167. Abdelbaky, M.; Peeters, J.R.; Dewulf, W. On the influence of second use, future battery technologies, and battery lifetime on the maximum recycled content of future electric vehicle batteries in Europe. Waste Manag. 2021, 125, 1-9. [CrossRef]

168. Arai, J.; Yamaki, T.; Yamauchi, S.; Yuasa, T.; Maeshima, T.; Sakai, T.; Koseki, M.; Horiba, T. Development of a high power lithium secondary battery for hybrid electric vehicles. J. Power Sources 2005, 146, 788-792. [CrossRef]

169. Vora, P.A. Modeling the impact of battery degradation within lifecycle cost-based design optimization of heavy-duty hybrid electric vehicles. Ann. Arbor: ProQuest Diss. Theses 2016, 875. Available online: https://docs.lib.purdue.edu/open_access_ dissertations / 875 (accessed on 1 August 2021).

170. Warner, J.T. Lithium-Ion Battery Chemistries; Elsevier: Amsterdam, The Netherlands, 2019; pp. 1-353.

171. Gianfranco, P.; Boryann, L. Behaviour of Lithium-Ion Batteries in Electric Vehicles; Springer: Berlin/Heidelberg, Germany, 2018; pp. 1-344. ISBN 978-3-319-69950-9.

172. Schismenos, S.; Chalaris, M.; Stevens, G. Battery hazards and safety: A scoping review for lead acid and silver-zinc batteries. Saf. Sci. 2021, 140, 105290. [CrossRef]

173. Moseley, P.; Bonnet, B.; Cooper, A.; Kellaway, M. Lead-acid battery chemistry adapted for hybrid electric vehicle duty. J. Power Sources 2007, 174, 49-53. [CrossRef]

174. Pradhan, S.K.; Chakraborty, B. Substrate materials and novel designs for bipolar lead-acid batteries: A review. J. Energy Storage 2020, 32, 101764. [CrossRef]

175. Tian, S.; Hong, M.; Ouyang, M. An Experimental Study and Nonlinear Modeling of Discharge I-V Behavior of Valve-Regulated Lead-Acid Batteries. IEEE Trans. Energy Convers. 2009, 24, 452-458. [CrossRef]

176. Bressanini, G.L.; Busarello, T.D.C.; Peres, A. Design and implementation of lead-acid battery state-of-health and state-of-charge measurements. In Proceedings of the 2017 Brazilian Power Electronics Conference (COBEP), Juiz de Fora, Brazil, 19-22 November 2017; pp. 1-6.

177. Moseley, P.; Rand, D.; Garche, J. Lead-acid batteries for future automobiles. In Lead-Acid Batteries for Future Automobiles; Elsevier: Amsterdam, The Netherlands, 2017; pp. 601-618.

178. Saiju, R.; Heier, S. Performance analysis of lead acid battery model for hybrid power system. In Proceedings of the 2008 IEEE/PES Transmission and Distribution Conference and Exposition, Chicago, IL, USA, 21-24 April 2008; pp. 1-6.

179. Zhu, T.; Wills, R.G.; Lot, R.; Kong, X.; Yan, X. Optimal sizing and sensitivity analysis of a battery-supercapacitor energy storage system for electric vehicles. Energy 2021, 221, 119851. [CrossRef]

180. Gong, J.; Wang, Y.; Zhao, A.; Zhao, Z. Optimal sizing of portable modular batteries for electric vehicles. J. Clean. Prod. 2020, 277, 123868. [CrossRef]

181. Hussain, A.; Bui, V.-H.; Kim, H.-M. Optimal Sizing of Battery Energy Storage System in a Fast EV Charging Station Considering Power Outages. IEEE Trans. Transp. Electrif. 2020, 6, 453-463. [CrossRef]

182. Bullock, K.R. Carbon reactions and effects on valve-regulated lead-acid (VRLA) battery cycle life in high-rate, partial state-ofcharge cycling. J. Power Sources 2010, 195, 4513-4519. [CrossRef]

183. Sawai, K.; Ohmae, T.; Suwaki, H.; Shiomi, M.; Osumi, S. Idling-stop vehicle road tests of advanced valve-regulated lead-acid (VRLA) battery. J. Power Sources 2007, 174, 54-60. [CrossRef]

184. Ohmae, T.; Sawai, K.; Shiomi, M.; Osumi, S. Advanced technologies in VRLA batteries for automotive applications. J. Power Sources 2006, 154, 523-529. [CrossRef] 
185. Li, G.; Lu, X.; Kim, Y.J.; Viswanathan, V.; Meinhardt, K.; Sprenkle, V. A Planar Zebra Battery Based on Low-Cost IntermediateTemperature $\mathrm{Na}-\mathrm{FeCl}_{2}$ Redox Chemistry. Electrochem. Soc. Abstr. 2015, 17, MA2015-026.

186. Ruiz, V.; Pfrang, A.; Kriston, A.; Omar, N.; van den Bossche, P.; Boon-Brett, L. A review of international abuse testing standards and regulations for lithium ion batteries in electric and hybrid electric vehicles. Renew. Sustain. Energy Rev. 2018, 81, 1427-1452. [CrossRef]

187. Balaji, J.; Sethuraman, G.M.; Roh, S.H.; Jung, H.Y. Recent developments in sol-gel based polymer electrolyte membranes for vanadium redox flow batteries-A review. Polym. Test. 2020, 89, 106567. [CrossRef]

188. Song, J.; Wang, Y.; Wan, C. Review of gel-type polymer electrolytes for lithium-ion batteries. J. Power Sources 1999, 77, $183-197$. [CrossRef]

189. Stephan, A.M. Review on gel polymer electrolytes for lithium batteries. Eur. Polym. J. 2006, 42, 21-42. [CrossRef]

190. Ren, W.; Ding, C.; Fu, X.; Huang, Y. Advanced gel polymer electrolytes for safe and durable lithium metal batteries: Challenges, strategies, and perspectives. Energy Storage Mater. 2021, 34, 515-535. [CrossRef]

191. Baazizi, M.; Dahbi, M.; Aqil, M.; Ghamouss, F.; Saadoune, I. A Ni-rich Cathode Material for Lithium-ion Batteries with Improved Safety and Cost. In Proceedings of the 2019 7th International Renewable and Sustainable Energy Conference (IRSEC), Agadir, Morocco, 27-30 November 2019; pp. 1-4.

192. Lande, L.; Kallitsis, E.; Hales, A.; Edge, S.J.; Korre, A.; Offer, G. Cost and carbon footprint reduction of electric vehicle lithium-ion batteries through efficient thermal management. Appl. Energy 2021, 289, 116737. [CrossRef]

193. Saxena, S.; Ning, Y.; Thompson, R.; Pecht, M. Role of the rest period in capacity fade of Graphite/LiCoO2 batteries. J. Power Sources 2021, 484, 229246. [CrossRef]

194. Zhang, L.; Liu, J.; Du, L.; Xu, X.; Ma, Y.; Qu, B.; Fan, P.; Yin, G.; Yang, F.; Zhu, L. Identifying the aging mechanism in multiple overdischarged $\mathrm{LiCoO}_{2} /$ mesocarbon microbeads batteries. Ceram. Int. 2021, 47, 21253-21262. [CrossRef]

195. Li, D.; Zhang, B.; Ou, X.; Zhang, J.; Meng, K.; Ji, G.; Li, P.; Xu, J. Ammonia leaching mechanism and kinetics of LiCoO 2 material from spent lithium-ion batteries. Chin. Chem. Lett. 2021, 32, 2333-2337. [CrossRef]

196. Prasad, K.H.; Julakanti, V.R.; Rangaraju, G.; Sumithra, M.; Sundaraganesan, N. Structural and ImpedanceStudies of Nanocrystalline $\mathrm{LiCoO}_{2}$ Particle. In Proceedings of the 2020 International Conference on System, Computation, Automation and Networking (ICSCAN), Puducherry, India, 27-28 March 2020; pp. 1-4.

197. Chen, S.; Zhang, X.; Xia, M.; Wei, K.; Zhang, L.; Zhang, X.; Cui, Y.; Shu, J. Issues and challenges of layered lithium nickel cobalt manganese oxides for lithium-ion batteries. J. Electroanal. Chem. 2021, 895, 115412. [CrossRef]

198. Bharathraj, S.; Adiga, S.; Mayya, K.; Song, T.; Kim, J.; Sung, Y. Degradation-guided optimization of charging protocol for cycle life enhancement of Li-ion batteries with Lithium Manganese Oxide-based cathodes. J. Power Sources 2020, 474, 228659. [CrossRef]

199. Horesh, N.; Quinn, C.; Wang, H.; Zane, R.; Ferry, M.; Tong, S.; Quinn, C.J. Driving to the future of energy storage: Techno-economic analysis of a novel method to recondition second life electric vehicle batteries. Appl. Energy 2021, 295, 117007. [CrossRef]

200. Wu, W.; Lin, B.; Xie, C.; Elliott, R.J.; Radcliffe, J. Does energy storage provide a profitable second life for electric vehicle batteries? Energy Econ. 2020, 92, 105010. [CrossRef]

201. Haram, M.H.S.M.; Lee, J.W.; Ramasamy, G.; Ngu, E.E.; Thiagarajah, S.P.; Lee, Y.H. Feasibility of utilising second life EV batteries: Applications, lifespan, economics, environmental impact, assessment, and challenges. Alex. Eng. J. 2021, 60, 4517-4536. [CrossRef]

202. Sun, S.I.; Chipperfield, A.J.; Kiaee, M.; Wills, R. Effects of market dynamics on the time-evolving price of second-life electric vehicle batteries. J. Energy Storage 2018, 19, 41-51. [CrossRef]

203. Behi, H.; Karimi, D.; Behi, M.; Ghanbarpour, M.; Jaguemont, J.; Sokkeh, M.A.; Gandoman, F.H.; Berecibar, M.; Van Mierlo, J. A new concept of thermal management system in Li-ion battery using air cooling and heat pipe for electric vehicles. Appl. Therm. Eng. 2020, 174, 115280. [CrossRef]

204. Akinlabi, A.H.; Solyali, D. Configuration, design, and optimization of air-cooled battery thermal management system for electric vehicles: A review. Renew. Sustain. Energy Rev. 2020, 125, 109815. [CrossRef]

205. Zhao, G.; Wang, X.; Negnevitsky, M.; Zhang, H. A review of air-cooling battery thermal management systems for electric and hybrid electric vehicles. J. Power Sources 2021, 501, 230001. [CrossRef]

206. Cheng, L.; Garg, A.; Jishnu, A.; Gao, L. Surrogate based multi-objective design optimization of lithium-ion battery air-cooled system in electric vehicles. J. Energy Storage 2020, 31, 101645. [CrossRef]

207. Guo, J.; Jiang, F. A novel electric vehicle thermal management system based on cooling and heating of batteries by refrigerant. Energy Convers. Manag. 2021, 237, 114145. [CrossRef]

208. Tang, X.; Guo, Q.; Li, M.; Wei, C.; Pan, Z.; Wang, Y. Performance analysis on liquid-cooled battery thermal management for electric vehicles based on machine learning. J. Power Sources 2021, 494, 229727. [CrossRef]

209. Akbarzadeh, M.; Jaguemont, J.; Kalogiannis, T.; Karimi, D.; He, J.; Jin, L.; Xie, P.; Van Mierlo, J.; Berecibar, M. A novel liquid cooling plate concept for thermal management of lithium-ion batteries in electric vehicles. Energy Convers. Manag. 2021, 231, 113862. [CrossRef]

210. Monika, K.; Chakraborty, C.; Roy, S.; Dinda, S.; Singh, S.A.; Datta, S.P. An improved mini-channel based liquid cooling strategy of prismatic $\mathrm{LiFePO}_{4}$ batteries for electric or hybrid vehicles. J. Energy Storage 2021, 35, 102301. [CrossRef]

211. Chung, Y.; Kim, M.S. Thermal analysis and pack level design of battery thermal management system with liquid cooling for electric vehicles. Energy Convers. Manag. 2019, 196, 105-116. [CrossRef] 
212. Tan, X.; Lyu, P.; Fan, Y.; Rao, J.; Ouyang, K. Numerical investigation of the direct liquid cooling of a fast-charging lithium-ion battery pack in hydrofluoroether. Appl. Therm. Eng. 2021, 196, 117279. [CrossRef]

213. Xu, H.; Zhang, X.; Xiang, G.; Li, H. Optimization of liquid cooling and heat dissipation system of lithium-ion battery packs of automobile. Case Stud. Therm. Eng. 2021, 26, 101012. [CrossRef]

214. Li, Y.; Guo, H.; Qi, F.; Guo, Z.; Li, M.; Tjernberg, L.B. Investigation on liquid cold plate thermal management system with heat pipes for $\mathrm{LiFePO}_{4}$ battery pack in electric vehicles. Appl. Therm. Eng. 2021, 185, 116382. [CrossRef]

215. Alaoui, C. Solid-State Thermal Management for Lithium-Ion EV Batteries. IEEE Trans. Veh. Technol. 2013, 62, 98-107. [CrossRef]

216. Hong, H.S.; Jang, S.D.; Park, S.; Yun, S.; Kim, Y. Thermal performance of direct two-phase refrigerant cooling for lithium-ion batteries in electric vehicles. Appl. Therm. Eng. 2020, 173, 115213. [CrossRef]

217. Shen, M.; Gao, Q. System simulation on refrigerant-based battery thermal management technology for electric vehicles. Energy Convers. Manag. 2020, 203, 112176. [CrossRef]

218. Gao, Q.; Liu, Y.; Wang, G.; Deng, F.; Zhu, J. An experimental investigation of refrigerant emergency spray on cooling and oxygen suppression for overheating power battery. J. Power Sources 2019, 415, 33-43. [CrossRef]

219. Wu, J.; Zhou, G.; Wang, M. A comprehensive assessment of refrigerants for cabin heating and cooling on electric vehicles. Appl. Therm. Eng. 2020, 174, 115258. [CrossRef]

220. Yun, S.; Hong, S.H.; Song, K.S.; Kwon, J.; Kim, Y. Experimental and numerical analyses of quenching performance of hot stamping blanks by two-phase refrigerant cooling using R1234yf. Int. J. Heat Mass Transf. 2021, 173, 121231. [CrossRef]

221. Putra, N.; Sandi, A.F.; Ariantara, B.; Abdullah, N.; Mahlia, T.M.I. Performance of beeswax phase change material (PCM) and heat pipe as passive battery cooling system for electric vehicles. Case Stud. Therm. Eng. 2020, 21, 100655. [CrossRef]

222. Koyama, R.; Arai, Y.; Yamauchi, Y.; Takeya, S.; Endo, F.; Hotta, A.; Ohmura, R. Thermophysical properties of trimethylolethane (TME) hydrate as phase change material for cooling lithium-ion battery in electric vehicle. J. Power Sources 2019, 427, 70-76. [CrossRef]

223. Shen, Z.-G.; Chen, S.; Liu, X.; Chen, B. A review on thermal management performance enhancement of phase change materials for vehicle lithium-ion batteries. Renew. Sustain. Energy Rev. 2021, 148, 111301. [CrossRef]

224. Niu, J.; Xie, N.; Zhong, Y.; Gao, X.; Fang, Y.; Zhang, Z. Numerical analysis of battery thermal management system coupling with low-thermal-conductive phase change material and liquid cooling. J. Energy Storage 2021, 39, 102605. [CrossRef]

225. Ping, P.; Zhang, Y.; Kong, D.; Du, J. Investigation on battery thermal management system combining phase changed material and liquid cooling considering non-uniform heat generation of battery. J. Energy Storage 2021, 36, 102448. [CrossRef]

226. Li, J.; Zhang, H. Thermal characteristics of power battery module with composite phase change material and external liquid cooling. Int. J. Heat Mass Transf. 2020, 156, 119820. [CrossRef]

227. Luo, M.; Song, J.; Ling, Z.; Zhang, Z.; Fang, X. Phase change material coat for battery thermal management with integrated rapid heating and cooling functions from $-40{ }^{\circ} \mathrm{C}$ to $50{ }^{\circ} \mathrm{C}$. Mater. Today Energy 2021, 20, 100652. [CrossRef]

228. Liu, Z.; Huang, J.; Cao, M.; Jiang, G.; Yan, Q.; Hu, J. Experimental study on the thermal management of batteries based on the coupling of composite phase change materials and liquid cooling. Appl. Therm. Eng. 2021, 185, 116415. [CrossRef]

229. Yang, Y.; Chen, L.; Yang, L.; Du, X. Numerical study of combined air and phase change cooling for lithium-ion battery during dynamic cycles. Int. J. Therm. Sci. 2021, 165, 106968. [CrossRef]

230. Lyu, Y.; Siddique, A.; Majid, S.; Biglarbegian, M.; Gadsden, S.; Mahmud, S. Electric vehicle battery thermal management system with thermoelectric cooling. Energy Rep. 2019, 5, 822-827. [CrossRef]

231. Lyu, Y.; Siddique, A.R.M.; Gadsden, S.A.; Mahmud, S. Experimental investigation of thermoelectric cooling for a new battery pack design in a copper holder. Results Eng. 2021, 10, 100214. [CrossRef]

232. Jiang, L.; Zhang, H.; Li, J.; Xia, P. Thermal performance of a cylindrical battery module impregnated with PCM composite based on thermoelectric cooling. Energy 2019, 188, 116048. [CrossRef]

233. Siddique, A.R.M.; Mahmud, S.; Van Heyst, B. A comprehensive review on a passive (phase change materials) and an active (thermoelectric cooler) battery thermal management system and their limitations. J. Power Sources 2018, 401, 224-237. [CrossRef]

234. Suh, I.-S.; Cho, H.; Lee, M. Feasibility study on thermoelectric device to energy storage system of an electric vehicle. Energy 2014, 76, 436-444. [CrossRef]

235. Yin, T.; Zhu, H.Z. Analytical model-based optimization of the thermoelectric cooler with temperature-dependent materials under different operating conditions. Appl. Energy 2021, 299, 117340. [CrossRef]

236. Zhou, Z.; Lv, Y.; Qu, J.; Sun, Q.; Grachev, D. Performance evaluation of hybrid oscillating heat pipe with carbon nanotube nanofluids for electric vehicle battery cooling. Appl. Therm. Eng. 2021, 196, 117300. [CrossRef]

237. Alaoui, C. Passive/Active BTMS For EV Lithium-Ion Batteries. IEEE Trans. Veh. Technol. 2018, 67, 3709-3719. [CrossRef]

238. Liu, F.; Lan, F.; Chen, J. Dynamic thermal characteristics of heat pipe via segmented thermal resistance model for electric vehicle battery cooling. J. Power Sources 2016, 321, 57-70. [CrossRef]

239. Tran, T.-H.; Harmand, S.; Sahut, B. Experimental investigation on heat pipe cooling for Hybrid Electric Vehicle and Electric Vehicle lithium-ion battery. J. Power Sources 2014, 265, 262-272. [CrossRef]

240. Bernagozzi, M.; Georgoulas, A.; Miché, N.; Rouaud, C.; Marengo, M. Novel battery thermal management system for electric vehicles with a loop heat pipe and graphite sheet inserts. Appl. Therm. Eng. 2021, 194, 117061. [CrossRef] 
241. Behi, H.; Karimi, D.; Behi, M.; Jaguemont, J.; Ghanbarpourd, M.; Behniae, M.; Berecibar, M.; Van Mierlo, J. Thermal management analysis using heat pipe in the high current discharging of lithium-ion battery in electric vehicles. J. Energy Storage 2020, 32, 101893. [CrossRef]

242. Yuan, X.; Tang, A.; Shan, C.; Liu, Z.; Li, J. Experimental investigation on thermal performance of a battery liquid cooling structure coupled with heat pipe. J. Energy Storage 2020, 32, 101984. [CrossRef]

243. Yao, M.; Gan, Y.; Liang, J.; Dong, D.; Ma, L.; Liu, J.; Luo, Q.; Li, Y. Performance simulation of a heat pipe and refrigerant-based lithium-ion battery thermal management system coupled with electric vehicle air-conditioning. Appl. Therm. Eng. 2021, 191, 116878. [CrossRef]

244. Kleiner, J.; Singh, R.; Schmid, M.; Komsiyska, L.; Elger, G.; Endisch, C. Influence of heat pipe assisted terminal cooling on the thermal behavior of a large prismatic lithium-ion cell during fast charging in electric vehicles. Appl. Therm. Eng. 2021, 188, 116328. [CrossRef]

245. Behi, H.; Behi, M.; Karimi, D.; Jaguemont, J.; Ghanbarpour, M.; Behnia, M.; Berecibar, M.; Van Mierlo, J. Heat pipe air-cooled thermal management system for lithium-ion batteries: High power applications. Appl. Therm. Eng. 2021, 183, 116240. [CrossRef]

246. Alihosseini, A.; Shafaee, M. Experimental study and numerical simulation of a Lithium-ion battery thermal management system using a heat pipe. J. Energy Storage 2021, 39, 102616. [CrossRef]

247. IEA. Global EV Outlook 2020. Technology Report. Available online: https://www.iea.org/reports/global-ev-outlook-2020 (accessed on 11 August 2021).

248. Jaguemont, J.; Karimi, D.; Van Mierlo, J. Investigation of a Passive Thermal Management System for Lithium-Ion Capacitors. IEEE Trans. Veh. Techno 2019, 68, 10518-10524. [CrossRef]

249. Lu, M.; Zhang, X.; Ji, J.; Xu, X.; Zhang, Y. Research progress on power battery cooling technology for electric vehicles. J. Energy Storage 2020, 27, 101155. [CrossRef]

250. Tete, P.R.; Gupta, M.M.; Joshi, S.S. Developments in battery thermal management systems for electric vehicles: A technical review. J. Energy Storage 2021, 35, 102255. [CrossRef]

251. Goli, P.; Balandin, A.A. Graphene-enhanced phase change materials for thermal management of battery packs. In Proceedings of the Fourteenth Intersociety Conference on Thermal and Thermomechanical Phenomena in Electronic Systems (ITherm), Orlando, FL, USA, 27-30 May 2014. [CrossRef]

252. Jaguemont, J.; Van Mierlo, J. A comprehensive review of future thermal management systems for battery electrified vehicles. J. Energy Storage 2020, 31, 101551. [CrossRef]

253. Kim, J.; Oh, J.; Lee, H. Review on battery thermal management system for electric vehicles. Appl. Therm. Eng. 2019, 149, 192-212. [CrossRef]

254. Arora, S. Selection of thermal management system for modular battery packs of electric vehicles: A review of existing and emerging technologies. J. Power Sources 2018, 400, 621-640. [CrossRef]

255. Hentunen, A.; Lehmuspelto, T.; Suomela, J. Time-Domain Parameter Extraction Method for Thévenin-Equivalent Circuit Battery Models. IEEE Trans. Energy Convers. 2014, 29, 558-566. [CrossRef]

256. Vatanparvar, K.; Faezi, S.; Burago, I.; Levorato, M.; Al Faruque, M.A. Extended Range Electric Vehicle With Driving Behavior Estimation in Energy Management. IEEE Trans. Smart Grid 2019, 10, 2959-2968. [CrossRef]

257. Zhu, C.; Li, X.; Song, L.; Xiang, L. Development of a theoretically based thermal model for lithium ion battery pack. J. Power Sources 2013, 223, 155-164. [CrossRef]

258. Worldwide Harmonised Light Vehicle Test Procedure (WLTP) Laboratory. WLTP Drive Cycle Data. Available online: https: / / www.wltpfacts.eu/ (accessed on 1 May 2021).

259. Ökten, G.; Liu, Y. Randomized quasi-Monte Carlo methods in global sensitivity analysis. Reliab. Eng. Syst. Saf. 2021, 210, 107520. [CrossRef]

260. Lamboni, M.; Iooss, B.; Popelin, A.-L.; Gamboa, F. Derivative-based global sensitivity measures: General links with Sobol' indices and numerical tests. Math. Comput. Simul. 2013, 87, 45-54. [CrossRef]

261. The Lithium-Ion Battery Life Cycle Report 2021. Circular Energy Storage. Available online: https://static1.squarespace. com/static/587657ddbe659497fb46664c/t/5fdaa991dc2ddb6396c30fa6/1608165783527/The+lithium-ion+battery+life+cycle+ report+sample.pdf (accessed on 10 May 2021).

262. Richa, K.; Babbitt, C.W.; Gaustad, G.; Wang, X. A future perspective on lithium-ion battery waste flows from electric vehicles. Resour. Conserv. Recycl. 2014, 83, 63-76. [CrossRef]

263. Earl, J.; Fell, M. Electric vehicle manufacturers' perceptions of the market potential for demand-side flexibility using electric vehicles in the United Kingdom. Energy Policy 2019, 129, 646-652. [CrossRef]

264. Shafique, M.; Rafiq, M.; Azam, A.; Luo, X. Material flow analysis for end-of-life lithium-ion batteries from battery electric vehicles in the USA and China. Resour. Conserv. Recycl 2021, 178, 1-13. [CrossRef]

265. Dehghani-Sanij, A.; Tharumalingam, E.; Dusseault, M.; Fraser, R. Study of energy storage systems and environmental challenges of batteries. Renew. Sustain. Energy Rev. 2019, 104, 192-208. [CrossRef]

266. Zubi, G.; Lópeza, R.D.; Carvalhob, M.; Pasaoglu, G. The lithium-ion battery: State of the art and future perspectives. Renew. Sustain. Energy Rev. 2018, 89, 292-308. [CrossRef] 